\title{
OF NAVAL COURTS MARTIAL AND PRIZE CLAIMS: SOME LEGAL CONSEQUENCES OF COMMODORE JOHNSTONE'S SECRET MISSION TO THE CAPE OF GOOD HOPE AND THE "BATTLE" OF SALDANHA BAY, 1781 (PART 2)*
}

\section{JP van Niekerk**}

Key words Maritime history; Cape of Good Hope; English maritime legal history; naval law and intra-naval immunity; prize law and joint captures

\section{Prize law}

\section{Introduction}

The possibility of financial gain to be derived from capturing enemy prizes was a central feature of Commodore Johnstone's Cape expedition ${ }^{284}$ and was no less important to those officers and seamen in his squadron. ${ }^{285}$ Not surprisingly therefore,

284 Harlow 1952: 110 observes that "prize and plunder seem to have been uppermost in his mind during and after the expedition to the Cape"; Rutherford 1942: 308 remarks that "[h]e still seems to have regarded his task from a privateering point of view and to have been obsessed by the thought of prizes to a degree remarkable even in an admiral of the period when important issues were at stake".

* Continued from (2015) 21 Fundamina. A J of Legal History 392-456.

** Professor, Department of Mercantile Law, School of Law, University of South Africa. 
the prizes that were taken during the campaign gave rise to fierce and prolonged litigation. First, though, it is necessary to describe some of the legal principles involved.

At common law, ${ }^{286}$ the capture, during war and wherever found, of an enemy ship, whether one of war or a merchantman, and her cargo as prize by a naval vessel ${ }^{287}$ set in motion an intricate and closely monitored legal process.

The captured property had to be taken as a matter of priority to an Admiralty Court $^{288}$ for formal adjudication. The legal duty imposed on captors to bring captured property in for adjudication sought to prevent indiscriminate seizures without a strict legal right - say of neutral property or outside of a formally declared war - and to prevent the right of seizure in time of war degenerating into piratical robbery. The Admiralty Court determined the validity of the capture in terms of international law - the law of war - and declared the prize either lawful or unlawful. In the latter case it ordered the property to be fully restored to the owner, either in specie or in the form of compensation or both. In the former case it declared the prize forfeited.

In principle, all forfeited prizes belonged to the Crown, on the basis that it alone could declare war and make peace. The Crown could deal with the forfeited prize as it saw fit: it could keep, abandon or even restore the prize. ${ }^{289}$

It could also, and most often did, grant the prize, or, more usually, the proceeds it realised at a sale under the auspices of the Admiralty Court, in full or in part, to those who had captured it or to whomever else it wished. A subject's claim to a prize, or to prize proceeds, was therefore subject to the consent and benevolence of the Crown. In the awarding of maritime prizes, the Crown was usually represented by the office of the Lord High Admiral, or, in later times when the office was put in commission, by the Lords Commissioners of the Admiralty who executed that office.

285 Thus, Pasley 1931: 175 was delighted that the naval action in Saldanha Bay was successful and, in a prescient anticipation of what was to materialise, wrote that no soldier landed until a full two hours after the captures had been effected. That meant that the Army had probably been deprived of any hope of sharing in the prize proceeds and that "the Sole and only Right to the Prizes remains in the Navy alone, which makes the Capture a very pretty subject if they get all safe home to Old England".

286 The sources consulted for the very broad exposition that follows, and from which further detail including references to specific authority may be garnered, include: Anon 1848: 282-330; Browne 1840: 262-266; Phillimore 1857: 354-365.

287 Or, less relevant for present purposes, a privateering vessel, that is, a privately armed vessel authorised, commissioned or licensed by the Crown or state by letters of marque, to act - to make reprisals - against the specified enemy.

288 Either the most convenient (ie, the closest) local Vice-Admiralty Court, which were British courts established in British settlements or colonies, or the High Court of Admiralty in London.

289 Thus, as Brown 1840: 262-263 explains, international law divests an enemy owner of his rights while municipal law vests it in the Crown (or state) and then further provides how the latter may deal with it. 
A perpetual royal grant to the Admiralty in 1665 included naval maritime captures of enemy ships coming into English ports and into roadsteads everywhere; captures made at sea by non-commissioned vessels; and derelicts. Such prizes became one of the perquisites to that office and were called droits of the Admiralty. Naval captures outside the scope of this grant did not belong to the Admiralty but remained with the Crown. Thus, naval captures at a time when there was no war and hence no enemy, or in a foreign port, or captures on the high seas by commissioned (naval or private) ships, did not belong to the Admiralty itself, but to the Crown.

In time of war, the Crown, in turn, could award to the actual captors, whether naval captors or commissioned privateers, the benefit of such maritime prizes as fell outside the grant to the Admiralty and thus remained at its disposal as part of its inherent prerogative. It would do so to reward the captors and to encourage others to do likewise. Although not obliged to do so, this came to be done as a matter of course. The award was most frequently made by means of legislation, usually in the form of a prize act. ${ }^{290}$ Such prize acts, and the rules or regulations made in terms of them by royal proclamation, also provided how - in what shares - the prize proceeds had to be distributed amongst the captor or captors to whom they had been awarded. Whether a prize belonged to the captor, depended upon whether the capture had been made not only in accordance with the international law of war (in which case the prize was a lawful one and belonged to the Crown, and could therefore be conferred by the Crown on, in this case, the captor), but also within the scope of the relevant prize act and proclamation.

Importantly, the royal grant to the Admiralty was an absolute and perpetual alienation by the Crown of its interest in prizes coming within the grant. Only Parliament could restore to the Crown its original rights in droits of the Admiralty. The royal grant to captors contained in prize acts and royal proclamations, by contrast, was merely a temporary transfer of a portion of the remaining rights of the Crown in naval prizes. It could be revoked, or restored, or simply not conferred, as the Crown wished. Also, the Crown could, if circumstances demanded, decide to grant a prize by other means, bypassing the prize acts, say by royal instructions. As will become clear, that is what happened with the Saldanha Bay prizes.

There is a distinction, therefore, between a naval prize condemned to the (Crown in its office of) Admiralty as a droit of the Admiralty, and a naval prize condemned to the Crown itself, by virtue of its prerogative, iure coronae, a distinction that is blurred but, as will appear shortly, not extinguished by reason of the fact that the Crown is represented as to the latter by the Admiralty. ${ }^{291}$

290 Usually a prize act was passed at the outbreak of a war, operated against a specified enemy and for a limited period of time (usually a year), and was, if necessary, periodically renewed for the duration of the war.

291 In the former case it is the Admiralty advocate and proctor who appears in the Admiralty Court and conducts the proceedings for condemnation, in the latter case it is the Queen's advocate and proctor, unless the prize and hence also the conduct of proceedings have been granted to the captors. See, further, eg, Tiverton 1914: 28. 
The periodic prize acts and proclamations also served another purpose. They conferred upon the relevant Admiralty Court an exclusive and temporary prize jurisdiction $^{292}$ to adjudicate the lawfulness or otherwise of prizes brought before it.

For present purposes, two pieces of legislation are relevant.

First there was the [Dutch] Prize Act, 1781. ${ }^{293}$ Amongst other matters, it extended the relevant provisions of previous prize acts still in force ${ }^{294}$ to prizes taken from the States General of the United Provinces since 20 December 1781 and during the continuance of the hostilities against the Netherlands by British warships or privateeers. ${ }^{295}$

The Navy Act, 1781, ${ }^{296}$ passed for the encouragement of seamen, conferred the right to Dutch prizes captured by warships on the captors. It determined in section 1 that flag officers, commanders and other officers, seamen, marines and soldiers on board every ship of war "shall have the sole Interest and Property" of and in all ships and goods they have taken since 20 December 1780 and during the continuance of the hostilities against the United Provinces after such ships and goods had been "finally adjudged lawful Prize to his Majesty" in any Admiralty Court. It further determined that such prizes had to be divided between the captors in such proportions and manner as His Majesty had already ordered by a Royal Proclamation of 27 December 1780 .

As far as the distribution, division, apportionment or sharing of prize proceeds amongst captors were concerned, it was a matter governed by municipal and not by international law. Several different - but for present purposes simplified - scenarios have to be distinguished.

Most straightforward was the situation where a single warship made the capture, in which case the prize proceeds had to be distributed amongst those involved with or on board her at the time of the capture. The manner of distribution in such a case - the relevant shares to be accorded to the individuals involved - was initially governed by custom or, later, specified by means of statute or royal proclamation. Thus, the flag officer, ${ }^{297}$ captain, officers and crew members of the capturing ship were entitled to share in the prize proceeds in specific proportions, decreasing in size in accordance with their rank.

In the case of a naval operation, again, where a squadron or several associated or co-operating ships were jointly involved in effecting a capture, the prizes taken were distributed amongst all the warships involved at the time of the capture. The

292 Only the Admiralty Court exercising its prize jurisdiction, and not common-law courts, could adjudicate prizes, and then only for so long (usually for the duration of a specified war) and in respect of such (specified) enemy property as was included in the jurisdiction that had been granted to it.

29321 Geo III c 5.

294 That is, the Prize Act, 1778 (18 Geo III c 15), the [French] Prize Act, 1779 (19 Geo III c 5, which extended the Act of 1778 to French prizes), and the [Spanish] Prize Act, 1780 (20 Geo III c 9, which extended the Act of 1778 to Spanish prizes).

295 Section 1. It also declared which goods were to be deemed military or ship stores (s 2).

29621 Geo III c 1.

297 As to whom see further par 322 below. 
inevitable practice in this case was for the Prize Court, that is, the Admiralty Court exercising its prize jurisdiction, to hold the joint captors ${ }^{298}$ entitled to share in the prize proceeds according to their relative strength - larger ships got proportionally more than smaller ones - because of the practical impossibility of establishing the extent to which their respective degrees of exertion had contributed to the capture. This was known as the general principle of relative strength, as determined by the size and compliment of the ships involved. Even should one particular naval vessel actually have contributed more than the others to a specific capture, and have been identifiable as the actual captor on the basis, say, of being the one to whom the enemy ship surrendered by striking her flag, no greater proportion was ever allowed her on that basis. The other ships present shared likewise as joint captors, on the ground of association and co-operation. If vessels were associated and co-operating, ${ }^{299} \mathrm{a}$ capture made by one of them (the actual captor) inured to the benefit of all the rest of them (the constructive captors). This rule of practice was regarded as being in accordance with the principles of natural equity and justice. ${ }^{300}$

In principle, ${ }^{301}$ the same applied in the case of an enemy capture by a privateer, or a group of privateers, except that then the distribution of what was the profits of the privateering venture amongst the crew of one privateering vessel, or amongst several privateers acting in consort, was usually provided for by way of an agreement. ${ }^{302}$

298 To be distinguished from joint capture is the case of rival claimants, where the claim of one was not to a share of a prize, but to the sole right to a prize to the exclusion of the other: see Tiverton 1914: 51.

299 A bond of association existed between, eg, warships comprising a blockading or a cruising squadron, or warships sailing together for a particular purpose under a single commander, and therefore not between all the ships in the Navy. Associated ships shared if the capture was made in connection with the purpose of their association. But association alone was not sufficient; there also had to be co-operation. Apart from actual co-operation (which could render ships joint actual captors), there was also co-operation with an actual captor, at least prima facie (a warship being under a continuous duty to attack the enemy), if a ship was in sight of the prize and the actual captor under circumstances sufficient to cause intimidation to the prize and encouragement to the captor (so-called constructive assistance).

300 As to joint capture, see specifically also Holland 1888: 74-75; Wheaton 1815: 287-289; Phillimore 1857: 356-359; and Tiverton 1814: 48.

301 Though not in detail. There was, eg, no presumption of assistance from another privateer in sight of the actual captor as there was in the case of naval vessels: privateers were entitled, but unlike warships not obliged, to capture enemy ships. Thus, in addition to being present, some overt act of actual assistance or intimidation was required to entitle a privateer to share with the actual captor.

302 Such an agreement could, of course, adopt general principles, such as that of distribution on the basis of relative strength, from naval practice and law. See, further, Starkey 1990: 279-280, pointing out that the net profits were split between the owners of privateering vessels and the investors or promoters; and the owners' share, or a part of it, was then further divided amongst the crew of the vessel. For early examples of and judicial decisions relating to the sharing of prizes amongst joint captors in terms of consortship agreements, see Marsden 1915: 308-311, 325-327, 349-351, 473-474. Commonly, it was agreed that the ships sailing in consort (and the captain and crew of each) would share in all captures made by any one of them while in the sight of the others or within twenty-four hours of losing sight, the sharing to be rateably according to their respective tonnage and manning ("ton for ton, man for man, according to the custom of the sea"). 
More complicated was the scenario involving a joint naval capture by different types of captor, such naval vessels and privateering vessels, or, relevant for present purposes, the Navy and the Army. ${ }^{303}$

And in this respect the litigation that followed on the capture of the Dutch prizes in Saldanha Bay provided some clarification, for there it was not only the naval squadron under Commodore Johnstone that was involved - and that thought itself to be entitled to the prize proceeds - but also the military component under General Medows.

First, though, a preliminary prize claim involving Johnstone himself.

\section{Johnstone's personal claim to an earlier prize}

When he was offered and accepted the appointment to lead the expedition to the Cape, Commodore Johnstone was as flag officer in charge of the naval squadron based at Lisbon, even though he was not always physically there.

The relevant Admiralty commission appointing him to the secret expedition was made out on 19 January 1781 and received by Johnstone, then at Spithead on the south coast of England, on 3 February and accepted by him shortly afterwards. Earlier, on 16 December 1780, Johnstone had, again from Spithead, given an order to one of the ships under his command at Lisbon to sail on a cruise. The order was received by the captain of the frigate in question on 17 January 1781 and she departed as instructed on 28 January. On 25 February she captured a Spanish prize.

Johnstone no doubt thought that as flag officer of the squadron to which the captor belonged, he was entitled to share in the prize. After all, the capture had been made on orders he had given while still in charge, even though the actual capture itself only took place after he had accepted another command. In any event, no other flag officer had been appointed in his place at the time of the capture, but equally, after 19 January no Admiralty orders had been addressed to him as commander of the Lisbon station.

At issue in Johnstone $v$ Margetson ${ }^{304}$ was the entitlement of a flag officer to share in the proceeds of a prize taken by ship under his command. By the time

303 A terrestrial prize taken by a capture affected by the Army, a land force, was called booty of war and was distinguished from a naval prize in some respects. Thus, although it was also usual for the Crown to grant a large booty to the troops involved and to specify its distribution amongst them, this was done by means of a special proclamation relating to the specific capture and not by means of a standing, albeit temporary, measure covering all captures made during a specific war, as was the case with naval prizes. The ad hoc granting of a booty of war did not set any precedent and did not entitle military captors to a similar award in future. However, the Admiralty Court was also given an exclusive statutory jurisdiction in respect of booty of war and its distribution, to be exercised according to the same procedure as in the case of naval prize. As to army prize, see further Anon 1848: 300-305.

304 (1789) 1 H Bl 261, 126 ER 153. See, further, also Prendergast 1852: 60-61 and 293-296. 
the claim was brought, in 1789 , Johnstone had died and the executor of his estate therefore claimed his one-eighth share of the prize, an amount of $£ 914$.

In terms of the proclamation governing the division of prizes in this instance, one of 25 June 1779, the captain of a warship was entitled to a three-eighth share (of the prize money allocated to her) if he was actually on board at the taking of the prize. ${ }^{305}$ However, if the capturing warship was under command of a flag, the flag officer, being actually on board or directing and assisting in the capture, was entitled to one-third of that three-eighths, that is, to one-eighth of the prize - the so-called "flag eighth" - and the relevant captain only to a two-eighth share. ${ }^{306}$

The argument on behalf of Johnstone was that although not on board at the time of the capture as was required of the capturing ship's captain himself, the capture had taken place under his direction. There was such direction or assistance, as the relevant proclamation required, because as flag officer he had given the orders; when not personally present, the only way a flag officer could assist or direct was by giving orders.

The defendant, again, contended that Johnstone's command did not continue until the time of the capture so as to entitle him to a one-eighth share. He had, by that time, accepted another command, that of "the expedition against the Cape of Good Hope" ${ }^{307}$ and the existing one therefore ceased as the duties of both together were incompatible. It was not necessary for Johnstone's command to end that another flag officer had to be appointed in his place. In this case there was neither the actual nor the constructive presence required for the flag officer to share. At the time of the capture, the captain of the frigate acted as the immediate officer of the Admiralty to which he was amenable, and he was thus entitled to the whole of his three-eighth share.

The Court of Common Pleas, per Lord Loughborough, held against Johnstone. It thought that for a flag officer to share in the captain's share under the proclamation, it was necessary, first, that an appropriate order should have been given and, secondly, that the capture should have been made under the actual command of $a$ flag officer, although not necessarily the same one that had given the order. The commission sent by the Admiralty to and accepted by Johnstone, appointing him to take another

305 Others on board received the following shares of her prize money: the other officers together got a two-eighth share, the midshipmen and warrant officers a one-eighth share, and all the other seamen on board a two-eighth share.

306 It seems that actually or constructively directing or assisting flag officers became entitled to a passive - share only from 1708 . This meant a flag officer got a share of all prizes taken by the ships under his command, even if he was not present at the time. Apart from the provisions entitling flag officers to share, other provisions, likewise refined in 1744 and restated in 1756, were designed to prevent disputes between flag offers, where several were involved or where one succeeded another. They were not relevant here as there was no other flag officer on the Lisbon station after Johnstone had quitted it and at the time of the capture.

307 At 266, 156. 
command, amounted to a termination of his command on the Lisbon station; on the acceptance of his new command, all his former duties and entitlements ceased. Thus, at the time of the capture, Johnstone was not, or no longer, the flag officer on the Lisbon station. ${ }^{308}$

\section{The Navy $v$ the Army: The preliminary judicial rulings}

The Saldanha Bay prize proceeds gave rise to litigation and a series of decisions involving rival claims by the Navy and the Army.

A few facts featured prominently and were not in dispute in the litigation: first, that a squadron of warships with a detachment of military - as opposed to marine - troops on board had been sent, as a conjoint force, with the sole object of attacking an enemy settlement, the Cape of Good Hope; secondly, that the secret royal instructions under the King's sign manual given to the two commanders of the expedition, Johnstone and Medows, directed that to avoid disputes concerning the distribution of any prizes or booty taken during the attack on the Cape by the joint operation of the Navy and the Army, such prizes had to be divided between the sea and the land forces in two shares according to the numbers mustered in each service ${ }^{309}$ thirdly, that the sea forces' share had to be divided according to naval regulations and that out of the land forces' share, its commander was to be entitled to the same share as was the naval commander in proportion to the naval share, with the remainder to be distributed among the army officers and men in proportion to their respective pay; and fourthly, that after the two forces had arrived within

308 See, further, Wheaton 1815: 294-296, pointing out that in terms of the proclamation and judicial decisions, there was no sharing by a flag officer in prizes made by (i) a ship on the station to which he had been sent to command before his arrival there; (ii) a reinforcing squadron before it arrived within the limits of his command and it actually received some or other order from him; (iii) a ship that had been detached by the Admiralty upon a secret service; (iv) a ship operating outside the limits of his station and without his orders; and (v) ships he had left behind to take up another distinct command or after he had been superseded.

309 As pointed out earlier (and see, also, Anon 1848: 294-296), under the perpetual grant of 1665, all non-commissioned captures belonged to the Lord High Admiral and were known as droits of the Admiralty. As a land force was not commissioned to engage in naval operations, a capture at sea by a land force (eg, by a canon shot from land) was considered a non-commissioned capture, the captured property was an Admiralty droit, and the land force had to be content to take its reward from the Admiralty and had no prize interest under any prize act or royal proclamation. However, maritime captures made by a mixed or conjunct naval and military force operating under special orders (as opposed to naval and military forces merely by chance having come together, or troops happening to be on board naval warships at the time of capture) were not included amongst droits of the Admiralty. And as they were not made by an exclusively naval force, they did not become a prize to the captors under the prize acts and proclamations. Rather, they were considered by the Admiralty Court as a prize or booty of war belonging to the Crown to be disposed of at pleasure, as in the case of booty captured by a land force alone. That was the position here, and one that the Crown fully appreciated, hence the special instructions issued as to the division of any prize proceeds. 
a certain distance of the Cape, no attack was made on the settlement, but that the naval squadron, while the troops were on board, took enemy prizes in an open and unfortified bay - and hence, at sea - at a great distance from the destined object of attack.

Several legal processes preceded the litigation.

In June 1782 a suit was instituted by the Navy in the Admiralty Court. It claimed the sole interest in one of the prizes ${ }^{310}$ under the [Dutch] Prize Act, 1781, and the proclamation made in terms of it, and prayed that the relevant Dutch ship and her cargo, having been taken by the naval squadron under Commodore Johnstone, be condemned as a lawful prize to the Crown.

On 4 September 1782, in the High Court of Admiralty, Sir James Marriot condemned the ship and cargo as lawful prize. However, he reserved the question of who were the captors on the ground that it could turn out that the Army was entitled (to share) under the secret instructions issued for the Cape expedition.

Later the High Court of Admiralty pronounced for the interest of the Army, in accordance with the spirit of the secret instructions, and decreed that the proceeds of the prize had to be distributed according to those instructions in equal shares.

Soon after the Admiralty Court's decree in September 1782, the prize agents, including John Pasley ${ }^{311}$ who had been appointed for the naval interests, caused the Dutch ship and her cargo to be sold. They received various large sums of money, part of which they distributed among the officers and crews of the ships in Johnstone's squadron. The residue remained in the hands of Pasley, to be distributed, according to him, in accordance with the [Dutch] Prize Act, 1781, and the proclamation. One of Johnstone's captains, Rodham Home of HMS Romney, Johnstone's flagship, actually sued Pasley in the King's Bench to recover damages from him for his refusal to pay him his share of the residue, a plea that was and remained pending there during the Admiralty proceedings described here.

Johnstone and the other naval officers and seamen in his squadron felt aggrieved by the decision of the Admiralty Court and appealed against its decree to the Court of the Lords Commissioners of Appeals from the Admiralty in Prize Causes.

On 30 June 1786, Lord Camden and two other of the Lords Commissioners considered the sole question, namely whether the Saldanha Bay capture came within the meaning of the [Dutch] Prize Act, 1781, or within the case alluded to by the secret instructions governing the Cape expedition. Their Lordships pronounced the captured ship and her cargo to have been taken "by the conjoint operation" of the naval ships employed on the expedition under the command of Johnstone, and of the Army under General Medows. They therefore condemned the jointly captured ship and the unclaimed part of her cargo "as lawful prize to the King", and not to either

310 Nominally the suit concerned only one of the captured vessels, namely the Hoogkarspel, and the litigation is occasionally referred to as that in The Hoogkarspel: see, eg, Anon 1848: 296-297.

311 It is not certain whether he was related to Capt (later Adm Sir) Thomas Pasley of HMS Jupiter: see again Van Niekerk 2015: at n 96. 
or both of the captors. Its sentence was therefore clearly in opposition to the right claimed by the Navy: the prizes were governed by the secret instructions and not by the [Dutch] Prize Act, 1781.

Afterwards, on 3 May 1788, the Lords Commissioners issued a monition - the term for a citation or summons issued by a civil court, such as an Admiralty Court to the naval prize agent Pasley to bring in an account of the sales of the prize property together with the proceeds of such part of it as might still be in his hands.

\section{The Navy v the Army: The Navy seeks to prohibit the Lords Commissioners of Appeals in Prize Causes}

The upshot of this legal maneuvering ${ }^{312}$ was that an application was made to the Court of Common Pleas in the name of Captain Rodham Home for a writ of prohibition to be issued against Earl Camden and the other Lords Commissioners to have their decision in the appeal from the Admiralty Court declared a nullity and so to prevent all further dealings in the Saldanha Bay prize proceeds.

In Home v Earl Camden \& Others ${ }^{313}$ the Navy, in the name of Home, prayed a prohibition on the ground that it had never been disputed that it belongs to the common-law courts at Westminster Hall to control the proceedings of all other courts, including the Admiralty Courts, if they transgressed the jurisdictional limits assigned to them. ${ }^{314}$

The Navy argued that the Lords Commissioners of Appeals in Prize Causes did not by law have the authority to take money arising from the sale of prize property that had been finally adjudged to be lawful prize to the Crown in the Admiralty Court, out of the hands of any appointed (naval) agent and to compel the agent to bring it into court; it therefore could not prevent Rodham, and by implication the other naval claimants, from recovering from Pasley his share, or damages for the non-payment of his share. ${ }^{315}$ Its contention in favour of an entitlement to a prohibition was that

312 There is a summary of the proceedings and sentences in the Admiralty Courts by Grose $\mathrm{J}$ at 401 , 1086 in the King's Bench decision (n 330 below). Further detail will no doubt be found in NA, HCA 32/1835 part 1 (Prize Appeals: Ship: Hoogsharpel, master Hernmeyer, Dutch, 1798); HCA 32/1835 part 2 (Prize Accounts for ships captured at Saldanha Bay, 1796); and HCA 32/1840 (Prize Appeals: Hoogskarpel (Harmeyer), 1795).

313 (1790) 1 H Bl 476, 126 ER 275 (CP); also reported in (1791) 2 Lawyer's and Magistrate's Magazine 241-256.

314 See at 515, 296.

315 Although the Navy admitted (at 515, 297) that the general question of whether a ship or goods taken at sea was a lawful prize or not, did not belong to common-law courts but solely to the Admiralty Court, the rights which an act of Parliament - here, specifically the [Dutch] Prize Act, 1781 - conferred in respect of a prize adjudicated by the Admiralty Court was the subject of an action at law and cognizable in the common-law courts. Here, it contended, the Navy had a right founded in the Prize Act and the Lords Commissioners were in the process of depriving it of that right or at least obstructing it in enforcing it. 
it was the Navy alone that was entitled to the prizes. The Army was not entitled as it was present and on board the naval vessels only for the reduction of the Cape settlement and not for any other service in the course of the expedition that might be the peculiar and proper business of the naval ships, for instance the capturing of enemy ships and cargoes. The [Dutch] Prize Act, 1781, it argued, applied to captures made prior to any attack on the settlement and not the secret instructions that had been issued for the joint operation and that alone made provision for an equal division between the two forces. ${ }^{316}$

The arguments raised by Lord Camden and the other Lords Commissioners against a prohibition were, first, that here the warships were not the sole captors; secondly, that the [Dutch] Prize Act, 1781, vested the right to a prize in naval ships only when they were the sole captors; and, thirdly, that the Prize Court had a general authority in all cases to distribute the shares of a prize and that the proposition was therefore untrue that they did not by law have the authority to take out of the hands of an agent the money arising from the sale of a prize, given that they did in fact have the right to order such proceeds to be brought into court. ${ }^{317}$

After hearing the initial arguments, Lord Loughborough expressed the Court's desire to hear further arguments on specific points that remained unclear, including the scope of the jurisdiction of the Admiralty Court prior to and after the promulgation of the prize acts. ${ }^{318}$

The Court then considered and responded to the three main arguments raised by the defendant Lords Commissioners ${ }^{319}$ against issuing a prohibition.

316 For the Navy's arguments, see at 490-494, 283-285.

317 For these arguments, see at 484-490, 280-283 and 515, 297.

318 His Lordship explained (at 495-496, 285-286) that he had initially formed the opinion that as the ship and her cargo had been condemned a lawful prize, the [Dutch] Prize Act, 1781, applied so that it was a case of "an unlimited, universal grant of the interest of the crown to the navy". However, the sentence of the Lords Commissioners evidently meant that by reason of the joint operation of the Navy and the Army, the property of the prizes taken rested with neither but in the Crown. However, it was not quite clear whether, as the case stood on the record, the Lords Commissioners had exceeded their power in merely issuing a monition to the agent to bring in the proceeds, so as, at that stage of the proceedings, to afford a ground for a prohibition. Also unclear was whether, given that there were many claimants concerned in appointing the agent, a single claimant should be permitted to object to the agent giving an account of the sales and carrying in the proceeds. Also not settled was the question of what the jurisdiction of Admiralty Court was prior to the prize acts: only to decide whether a capture was legal or not, and not also to determine who was entitled to it (except, that is, to determine disputes between grantees of the Crown), given that the sole ownership of property taken by naval ships was in the Crown? The prize acts had apparently introduced new law: it had vested, by the force of a parliamentary grant, a title to all prizes taken at sea in the Navy. No jurisdiction existing in the Admiralty Court prior to the prize acts could therefore entitle that Court, having decided the issue of the lawfulness of a prize, to decide the question of the property in a prize contrary to terms of that Act.

319 See at 515, 297. 
The Court rejected their first and second arguments, namely that the naval vessels were not the sole captors as the Saldanha Bay prizes were taken by a joint service, and that the Navy therefore did not obtain any rights under the [Dutch] Prize Act, 1781. It pointed out ${ }^{320}$ that it was not clear from the record that the Army had given any aid, or what aid it had given, in the capture of the enemy ships. The troops were present on board the ships not as soldiers but like passengers, and were not carrying out any operation under the command of their officers. On the facts it had to be assumed that the warships were the sole captors and that, as such, they were entitled to the prizes under the [Dutch] Prize Act, 1781. The Navy was therefore entitled to a prohibition if it could show an act done by the Lords Commissioners contrary to its right.

As to the third argument concerning the scope of the Admiralty Court's jurisdiction in prize matters, the Court thought ${ }^{321}$ that the High Court of Admiralty had correctly assumed and based its decision on the notion that in the event of any co-operation by another force besides the warships, the matter fell entirely outside of the [Dutch] Prize Act, 1781. Hence it had declared the Saldanha Bay captures not merely lawful prize (to the undisputed captors), but also lawful prize to the Crown by royal prerogative, and accordingly at the Crown's disposal. In terms of the Prize Act, it explained, the naval officers and crew had the sole interest in a prize declared lawfully captured, because the effect of that Act was a parliamentary gift by the Crown of the interest it would have had, or had before, to the officers and crews of capturing warships. The Act operated to transfer the sole interest and property previously in the Crown. However, that only concerned prizes taken at sea. It could also cover certain instances of joint capture by warships and a foreign allied force, or a privateer or a non-commissioned ship. In all these cases, the property of what the warships took had uniformly and repeatedly been adjudged to the officers and crew of the warship: "[t]hey are solely entitled to what they take, not to what they solely take". Co-captors have the right in some cases for a quantum meruit for assistance they had given and in other cases they have been held to have a distinct and specific share in the capture. But in no case did that destroy the vested right which warships solely have in the capture they have made. If, say, a warship and a privateer effected a joint capture, both were solely entitled (to their respective shares) and it was not the case that the prize belonged to neither (but to the Crown) merely because of their joint capture.

In the present case, the Court explained, ${ }^{322}$ there was a joint expedition by sea and land forces and a capture of enemy ships on (as was always supposed) the high seas. It was not a case of the reduction of a part of the enemy's territory where the property taken could be on land, or in port and where, because it could be difficult to

320 See at 516-517, 297-298.

321 See at 517-519, 298-299.

322 See at 519-520, 299. 
determine which of the sea or land force contributed and to what extent, instructions were usually given for the distribution of such prize or booty as may be taken. However, such instructions never intended giving to any subject the prizes taken on the high seas by warships. A parliamentary grant (in terms of the Prize Act) could not be controlled by the effect of a grant under the King's sign manual (in terms of such instructions). The Crown had no property to grant by instructions as it had parted with it all in terms of the Prize Act. A marine prize - ships taken on the high seas, and not as booty as result of the reduction of a territory - was subject to the Prize Act and belonged solely to the warship.

Thus, the Court continued, ${ }^{323}$ while the co-operation of the Army could give it a right to share, that could not totally destroy or annul the right of the Navy. An interest in a prize taken at sea (and covered by the Prize Act) could be shared or distributed, but could not be taken away; an interest vested after the adjudication of a lawful prize, in consequence of a parliamentary grant (in the form of the Prize Act), could not be annulled or destroyed. It was not the case that warships had a vested right only if they were the sole captors and hence no such right where any assistance was given, but that where as captors they had a vested right, it was subject to such a claim for assistance as any other party could make. It did not appear that any assistance had been given by any other force so as to make it a joint operation. And an interpretation of the Admiralty Court's sentence did not contradict this. ${ }^{324}$

As to the Lords Commissioners' monition directed to the prize agent to bring in the residue of the prize proceeds in his hands, the Court explained ${ }^{325}$ that such a monition was a very usual one for an Admiralty Court, including the Court of Prize Appeals, to make where the subject of a suit was not deemed to be a legal prize and where it was accordingly not vested in the captors and restitution had to be made. However, here the prize had been declared lawful and a legal right had vested. The intention of the [Dutch] Prize Act, 1781, was obvious: if once a prize had been adjudged by the Admiralty Court, the distribution of the interest in that prize had to be managed as was the distribution of any other legal, vested right according to the laws of the land, namely by an action in a court of law. The clear direction of the Prize Act, it seemed to the Court, ${ }^{326}$ was that prize money had to remain in the hands of the prize agent, who was liable to the actions of those who had a legal right in it. And against the primary interest of those persons, the money was not to be taken out of the agent's hands by an order of the Admiralty Court.

323 See at 520-521, 299-300.

324 See at 521-522, 300. As adjudged by the Admiralty Court, the warships had reduced the prize and it was adjudged to have been lawfully taken by warships having military troops on board. As such the Army became entitled to come in for a participation under the Prize Act and the Proclamation, but that did not prevent a right from vesting in the Navy. The premise assumed by the sentence of the Admiralty Court did not appear to form any conclusion that the Navy was not entitled.

325 See at 522-523, 300-301.

326 See at $524-525,301$. 
Thus, the Court concluded, ${ }^{327}$ if it were taken that according to the sentence of the Admiralty Court there was no vested right in the officers and crew of the warships, nor any in the Army, but only in Crown in its prerogative, the Crown could dispose of that interest to such uses as it thought fit. The monition it issued was perfectly consistent with such a construction. However, it was inconsistent with the well-founded notion that under the Prize Act, after the adjudication of a lawful prize, the plaintiff here and all other officers and crews of the warships involved had a vested legal right. Then the effect of the monition was directly in prejudice of the right of action of all others concerned and it interfered with the legal duty imposed on the agent in the case of captures at sea. The earlier proceedings in the Admiralty Courts prevented the plaintiff and other naval claimants from recovering a legal, vested right and subjected all others interested in the actions of the agents ${ }^{328}$ to the decision of the Admiralty Court. In contrast, the Court's construction of the Prize Act was that all those rights had to be enforced in common-law courts and did not belong to prize courts.

Therefore, upon the face of his declaration, the plaintiff Home and hence the Navy had a legal, vested right in the subject of the Lords Commissioners' monition, and an Admiralty Court could not deprive him of that right, could not do anything prejudicial to that right, and could not prevent or obstruct the plaintiff in the recovery of that right.

Therefore, on 23 June 1790, the Court of Common Pleas gave judgment for the plaintiff in prohibition to the Court of the Lords Commissioners of Prize Appeals because its monition was contrary to the legal, vested right of the officers and crews of the squadron. ${ }^{329}$

\section{The Navy v the Army: The Lords Commissioners of Appeals in Prize Causes go on appeal}

Not surprisingly, the Lords Commissioners of Appeals in Prize Causes were not happy with this curtailment of their jurisdiction and went on appeal to the King's Bench.

In Lord Camden \& Others $v H_{0} e^{330}$ the judgment below was reversed on 11 November 1791. ${ }^{331}$

The King's Bench held that, notwithstanding any of prize acts, the Prize Court the Admiralty Court exercising its prize jurisdiction - and the Lords Commissioners

327 See at 525-526, 301-302.

328 Including the Greenwich Hospital which was entitled to its share of the naval capture: see, further, n 347 below.

329 See at $526,302$.

330 (1791) 4 TR 382, 100 ER 1076 (KB).

331 See at 384,1077 for the arguments against a prohibition, and at 389, 1080 for the arguments in favour of a prohibition. 
of Prize Appeals had sole and exclusive jurisdiction over questions of prize and its incidents, that is, the question whether there was or was not a lawful prize and also the question of who were the captors. If it pronounced a sentence of condemnation, adjudging also who were the captors, the common-law courts could not examine the justice or propriety of its sentence, even though they would perhaps have put a different construction on the prize acts. Likewise, those courts had the power to enforce their decrees. Accordingly, the King's Bench refused to grant a prohibition where the Lords Commissioners had after a sentence issued a monition to a navy agent, employed by persons supposed to be entitled to the prize, requiring him to bring the proceeds of the prize into court to be distributed among persons declared entitled to it by their sentence.

The gist of the several judgments delivered in the King's Bench may be considered very briefly. ${ }^{332}$

As to the scope of the jurisdiction of Admiralty Courts in prize matters, the Court was clear that prize courts alone had jurisdiction over and were the sole judges of questions of prize. That included not only the question of whether or not a prize was lawful, but also that of the identity of the captors of the prizes they were called to adjudicate upon. Likewise, the manner in which prize proceeds were to be divided among those who were declared to be captors, had to be determined by those courts. ${ }^{333}$ And, even more broadly, they also had such jurisdiction over all matters that arose incidentally in construing statutes or proclamations - such as the prize acts - in order to form an opinion on any of these questions of prize.

332 Lord Kenyon CJ at 393-395, 1082-1083; Ashhurst J at 395-396, 1083; Buller J at 396-400, 10831085; Grose J at 400-401, 1085-1086.

333 Some years before, in Parker v Toulmin (1786) 1 Cox 264, 29 ER 1159, the question of which court had jurisdiction over the distribution of a prize had arisen in the Court of Equity, sitting at Lincoln Inn Hall, before Sir Lloyd Kenyon MR. A claim had been brought by the executors of the late Sir Hyde Parker against Toulmin (the son of a prize agent) for his one-eighth share in the proceeds from two Dutch vessels captured as prizes during the Anglo-Dutch War. The question was whether the capturing sloop, having been ordered around from Portsmouth to Dublin on a special assignment, was, at the time of the capture, one of the squadron under the flag of Parker, commanding at Portsmouth. Parker argued that the question of the lawfulness or otherwise of a capture unquestionably belonged exclusively to the Prize Court. However, once condemned, common-law courts had concurrent jurisdiction with prize courts in determining the distribution of the shares in prize proceeds in terms of applicable statutes and proclamations. He referred, inter alia, to a positive opinion to that effect of Lord Mansfield in Sutton v Johnstone. Toulmin thought the cases referred to were distinguishable as they related merely to the distribution of prize money amongst individuals of a ship to which the prize had been condemned, whereas here it was necessary that the prize should be condemned to the capturing sloop "as one of the squadron" under Parker before he could be entitled to his one-eighth. Prize courts, he thought, had exclusive jurisdiction over the question prize or no prize, as well as all its consequences. The Court thought there was great weight in Toulmin's distinction, but would not determine this doubtful question, and merely granted the parties leave to proceed in a court of law if they thought fit. 
This being so, there could be no objection to, nor interference by a commonlaw court with, the Lords Commissioners' sentence itself. Here they interpreted the [Dutch] Prize Act, 1781, and concluded that the case did not come within it. ${ }^{334}$ That decision was unchallengeable, even if a common-law court thought it an incorrect interpretation of the legislation. ${ }^{335}$

The underlying decision was that this was a joint capture by the Navy and the Army and that the prize taken was a good and lawful prize to the Crown. In consequence, persons claiming under the Prize Act had no right; it was not a case provided for by the Act but one falling within the secret instructions. The sentence was therefore clearly in opposition to the right claimed by the Navy. The decision that it was an instance of a joint capture by the Navy and the Army was one on the facts. That result, too, was unchallengeable, even if a common-law court thought it was an incorrect conclusion on the facts. ${ }^{336}$

If the Lords Commissioners had jurisdiction, even if they had made a mistake in their judgment, no grounds for prohibition existed, but at most a ground for appeal. ${ }^{337}$

There could likewise be no objection that by issuing the monition, the Prize Court had exceeded its jurisdiction as it was a necessary consequence of the earlier sentence. A prize court had the power to enforce its decrees. The only possible objection was that it had erroneously granted a monition to a person in possession of the proceeds to bring them into court to answer the several claims that could be made; the objection was that the monition was wrong because the proceeds of the prize were already in the hands of a duly appointed naval agent. Indeed, if the naval officers were the only persons entitled to the prize proceeds, this objection would have had considerable force. But it appeared from the sentence of the Lords Commissioners that other persons were interested besides those by whom the agent had been appointed. Being a joint capture, the Army was equally entitled to appoint an agent or to concur in the appointment of one; the Navy was not entitled to the whole of the proceeds and it could not contend that its agent ought to be entrusted with all the proceeds of the prizes. Therefore there was no reason why the proceeds should not be taken out of the possession of the naval agent and put under control of

334 Even if it did, the Crown had the right under the Prize Act to distribute captured prizes in such proportions as it may declare by proclamation. Here it declared in secret instructions, which had the effect of a proclamation, that in the event of a joint capture by the Navy and the Army the prizes taken by them should be distributed in a manner different from that insisted on by the Navy.

335 The King's Bench did not think so. The Prize Act attached only to captures by ships. All its provisions concerned captures of that description and they did not extend to joint captures by the Navy and the Army. That may well have been an omission, but the position was nevertheless clear.

336 Whether the capture here was one by the Navy only, or a joint capture by the Navy and the Army, was a question of fact, of which prize courts were the proper judges; their conclusion could not be contested.

337 The ground upon which the Court of Common Pleas had proceeded was that it thought the Lords Commissioners had misconstrued the Prize Act, and for that reason it granted a prohibition. However a common-law court could in the view of the King's Bench not examine that question. 
those who would take care of the interests of all the parties concerned. Prize courts were trustees for both the Navy and the Army and it was proper, for the interest of all, that the proceeds should be brought into court until the several claims could be adjusted.

Accordingly the monition to bring the proceeds into court had been properly issued, was not in excess of the Prize Court's jurisdiction, and therefore a prohibition ought to be refused in this case. The King's Bench therefore reversed the judgment of the Court of Common Pleas below that had granted a prohibition.

\section{The Navy v the Army: The Navy goes to the House of Lords}

Aggrieved by the decision of the King's Bench, which had in effect obliged their agent, Pasley, to give an account of the proceeds of the Saldanha Bay prizes and to bring the remainder into court and under control of the Prize Court for distribution to the Army too, the Navy took the matter to the House of Lords.

In Home $v$ Earl Camden \& Others ${ }^{338}$ the question posed to the judges was whether the Navy's declaration founding its appeal was sufficient in law to bar the Lords Commissioners from proceeding against naval agent Pasley to compel him to bring in the proceeds of the sale of the Saldanha Bay prizes. It held in the negative.

On 22 June 1795 the House of Lords accordingly affirmed the judgment of the Court of King's Bench that had refused a prohibition, albeit not on the same considerations. It focused, rather, on the requirements for a prohibition to be issued.

First, it observed that a clear ground of prohibition was that a court had exceeded its jurisdiction. An essential part of the jurisdiction of a prize court was that it has power and jurisdiction to ensure that the proceeds of a lawfully declared prize came into the hands of those it had declared entitled to it as captors. It was not true that after its sentence, a prize court becomes functus officio and that anything it subsequently did would exceed its jurisdiction. In short, the monition here was not issued in excess of its jurisdiction.

Less clear, though, was whether an injustice to a litigant, while proceeding within its jurisdiction, by refusing the litigant a benefit allowed by the common law or a statute, was a matter for prohibition (so that the law could be uniformly interpreted in all courts) or for appeal (on the basis that it was rather a matter of error). But the House then did not answer the question whether the injustice here, allegedly because of a misinterpretation of a statute (the Prize Act) by an inferior court (the Prize Court), ${ }^{339}$ the consideration of which arose incidentally in the course of proceeding which were admittedly within its jurisdiction (prize proceedings), could be a ground

338 (1795) 6 Bro PC 203, 2 ER 1028 (HL) (which contains a record of the earlier proceedings in the Court of Common Pleas and the arguments in the House) and (1795) $2 \mathrm{H} \mathrm{Bl} \mathrm{533,126} \mathrm{ER} 687$ (HL) (which contains the judgment of the House). 
for prohibition, or whether it was not rather a matter of appeal. It thought that clearly in such a case a prohibition will not lie, unless it was made apparent to the superior court that the party applying for the prohibition (the Navy) had in the course of the proceedings in the inferior court alleged grounds for a contrary interpretation of the statute on which it applies for a prohibition and that the inferior court had proceeded notwithstanding such allegation. And here that was not made apparent. ${ }^{340}$

Secondly, and more directly concerned with prize law, the House of Lords thought that prior to the ultimate adjudication by a prize court, no right vested by any of the prize acts in the captor of an enemy ship and cargo during war. Pending final adjudication, the ship and goods remained in the custody and protection of the prize court, in the interest of all those concerned in the capture. ${ }^{341}$ It was simply inconsistent with the plan of the prize acts that interest and property can vest in the captors at any time before the final adjudication in a prize court of appeal. ${ }^{342}$

Therefore, the Court of the Lords Commissioners of Appeals in Prize Causes' issuing of a monition to prize agents to bring in the proceeds of a ship and her cargo which had been sold after a sentence of condemnation as a lawful prize, but from which sentence there was an appeal (on a subject distinct from the question whether

339 The basis of the Navy's application for a prohibition to restrain the Prize Court from issuing process was a supposed contravention of the prize acts then in force, which it had misinterpreted. But the Navy had not established that the Prize Court had contravened the prize acts, either directly or indirectly or by misinterpreting them.

340 Put differently, even if the Navy had established that the Prize Court had misinterpreted the Prize Act - which it arguably had not done - it would have had to show that it had argued for an alternative interpretation before the Prize Court which the latter had rejected. And that it had not done.

341 Thus, if it was correct that no interest or property vested in the Navy as captor until the final adjudication by the Lords Commissioners, it followed that the naval agent Pasley's proceeding to sell and distribute part of the proceeds after the sentence in the Admiralty Court must have been without authority or at least not under the authority of the Prize Court. If under its authority by common assent and practice, then the agent at least remained accountable to that Court. Although an agent may be appointed before, he has strictly speaking nothing to do until after the final adjudication.

342 Throughout the litigation, it was agreed that the [Dutch] Prize Act, 1781, involved a parliamentary grant by the Crown to the captors of its interest in captures made by the warships. The Navy had the sole interest and property in prizes so captured. It was not clearly stated when this sole interest and property vested, the only reference being to property "finally adjudged lawful prize to his majesty". There was no definite point, but it lay somewhere between the original sentence of condemnation in the Prize Court in which the ship was first libelled, and the final sentence of condemnation in the Court of Appeal in Prize Causes. Disputes by joint captors could be raised only after the initial condemnation as a lawful prize. The effect of an appeal was to suspend the force of the sentence, not necessarily delaying or staying an execution. But from the moment of an appeal being interposed, the sentence was no longer final but liable to be reversed in part or in whole. Vesting clearly cannot be as soon as a prize had been declared lawful but while the court reserved the issue of who was the captor. And even if the sentence declared the prize lawful and determined who the captor was, vesting was possible only if there was no appeal. 
there was a prize or not, which, it was not disputed, was the case here), was not ground for a prohibition to be issued to that Court. The monition, after all, neither interfered with nor defeated any vested rights.

Further, here the Navy had based its appeal on its position as sole captor and only beneficiary of the prize proceeds under the Prize Act. But this was directly contrary to the Prize Court's sentence of condemnation, which could not be contested in a common-law court, and was therefore inadmissible, ill pleaded and rejectable. The same went for its allegation that under the Prize Act navy agents had the entire disposition of a prize. If the Navy were not the sole captor, or not a captor at all, it could not have the only, or any, claim to the prize proceeds.

But who were the captors here? That was determinable from the Prize Court's sentence (and not from the Navy's declaration) as it was a "matter of adjudication by a court of exclusive jurisdiction". ${ }^{343}$ Clearly the sentence was not an adjudication that the Navy was the sole captor of the Dutch ships. It may be that the Navy was a joint captor (but that was irrelevant and of no assistance in this cause) for even as a joint captor the Navy could never have the sole interest and property in the prizes and a navy agent could not have sole control of the proceeds. The prize acts have simply not provided for cases of joint captures, and in any event apply only to purely naval captures. It was perfectly impossible to found a right of sole agency upon a joint capture; and impossible to frame a joint agency under the prize acts which could be effectual.

In consequence, the Lords Commissioners' monition had to issue of necessity to execute its sentence, in so far as it determined that the Navy was a joint, or at least not the sole, captor.

In passing, the House, per Eyre JCJ, made an interesting and telling observation. ${ }^{344}$ It had become apparent during the course of argument that it was the sentence of the Lords Commissioners of Prize Appeals, and not their monition, which was the real cause for complaint in this matter. The Navy's complaint in the common-law courts was not that the sentence was wrong, "which indeed the temporal court had no jurisdiction to correct if it were wrong", nor indeed that the sentence was in excess of its jurisdiction or any other ground for prohibiting the Prize Court to carry it into execution. Its complaint was that the Lords Commissioners could not take the prize proceeds out of the navy agent's hands, and that was untenable.

In short, the Navy should, but could not, have appealed the decision of the Lords Commissioners holding that it was a joint, and therefore not the sole, captor. Instead its only option, to contest that body's jurisdiction in the common-law courts, was, after litigation lasting thirteen years, ${ }^{345}$ doomed to failure.

343 See at 545, 693-694.

344 See (1795) 6 Bro PC 203, 2 ER 1028 (HL) at 204, 1029; and (1795) 2 H Bl 533, 126 ER 687 (HL) at $546,694$.

345 From Jun 1782 to Jun 1795. 
The prize proceeds derived from the Saldanha Bay prizes were shared between the Navy and the Army, as provided for in the royal instructions issued for the Cape expedition.

A royal warrant of 20 May 1796 to the registrar of the Court of Appeals for Prize Causes directed that the proceeds of the Saldanha Bay prizes had to be divided between the Navy and the Army employed by that expedition. ${ }^{346}$

The Army got its share ${ }^{347}$ and the appropriate notices were given by the Army Agent for the Saldanha Bay Prize Money for the payment of individual shares. ${ }^{348}$ The initial division of prize proceeds by the naval agent to the Navy only ${ }^{349}$ had to be revised. Appropriate notices were given. ${ }^{350}$

The principle established by the Hoogkarspel litigation was followed in later decisions: ${ }^{351}$ captures made by a conjunct naval and military expedition, although still within the jurisdiction of prize courts for purposes of condemnation, fell outside

346 See Lumley $v$ Sutton at n 362 below.

347 Just as the Greenwich Hospital was entitled to a share in all naval prizes (Anon 1848: 297), so was the Royal Hospital in Chelsea entitled to share in military booty and prizes, including the Army's share of the Saldanha Bay prizes: see further NA, WO 164/480 (Saldanha Bay, 1781, Royal Hospital Chelsea: Prize Records). The various payments to the military regiments involved are reflected in WO 164/22-29 and /479 (Saldanha Bay, 1781 (Dutch East India ships captured)).

348 Thus, in (14-18 Jun 1796) no 13902, London Gazette at 583, notice was given that the Crown had directed that money arising from sale of the Saldanha Bay prizes should be divided between the land forces under command of Genl Medows and the sea forces under the late Commodore Johnstone, who were present at their capture on $21 \mathrm{Jul} 1781$, according to the numbers mustered in each service. The agent for the Army indicated that he would immediately proceed to make a distribution of the greatest part of the sum in his hands, and that he intended to make a second payment from the remainder and the interest that may be recovered. He accordingly gave notice that he would pay a proportion of that prize money, equal to one years' pay for each rank, in pursuance of the royal instructions, at the places and times and in the order specified in the notice.

349 See again at $\mathrm{n} 311$ above. As alluded to earlier, such division and payment prior to the final adjudication was probably unauthorised: see $\mathrm{n} 341$ above.

350 Thus, in (19-23 Jul 1796) no 13914 London Gazette at 705, notice was given that the Crown had directed that the money arising from the sale of the Saldanha Bay prizes, captured in there on 21 Jul 1781 by a squadron under Commodore Johnstone and finally adjudged by the House of Lord to the Crown "Jure Coronae", should be divided between the said squadron and the Army under Genl Medows, according to the numbers mustered in each service, deducting from the share of the said squadron the sum of $£ 68000$ received by their agents for distribution in the year 1785 . Notice was given to captains, officers and seamen actually on board the squadron under Johnstone on $21 \mathrm{Jul}$ 1781, that their respective shares of the remainder of the sum granted them by the Crown would be paid to them, or their attorney, by John Pasley, the surviving agent for that squadron, at places and on dates specified in the notice.

351 See, eg, the case arising from the capture of French ships at the surrender of Mauritius in 1810 to Adm Bertie and Genl Abercrombie (La Bellone (1818) 2 Dods 343, 165 ER 1508), and the case of booty arising from the surrender of Genoa to combined sea and land forces under Adm Pellew and Genl Bentinck (Genoa \& Dependencies, In re Greenwich Hospital Claim (1820) 2 Dods 444, 165 ER 1541). 
the prize acts which were concerned only with maritime captures by purely naval forces; they did not belong to or enure to the benefit of either or both of the captor forces, but was prize or booty solely at the disposition of the Crown. ${ }^{352}$

But, of course, it applied only to conjoint forces, and hence the Army's mere presence at a sea battle without any contribution of actual and material assistance did not entitle it to a share in the prizes taken by the Navy, as subsequently happened in Saldanha Bay in $1796 .{ }^{353}$

\section{A seaman's claim for his share of the Saldanha Bay prize proceeds}

It was not only the Navy itself that turned to the courts to claim its share of the Saldanha Bay prize proceeds. Ordinary seamen, too, were compelled to litigate to obtain their share of the Navy's share.

On the Cape expedition, one Macdonald was a sailor on board HMS Romney, Johnstone's flagship under the command of Captain Rodham Home. In November 1789 , already some eight years after the captures at Saldanha Bay, he issued a note giving authority to one Abraham Joseph or the latter's order to receive, from the vessel's prize agent, his share of the prize money allocated to the Romney for the prizes captured by the fleet under Johnstone. Such notes served to authorise third parties to receive (at a future date) a sailor's wages or his share of the prize money in exchange for the (immediate) payment of a (lesser) consideration. The agent in question was none other than John Pasley.

The prize money - payable to Macdonald in four instalments, namely $£ 34 \mathrm{~s}, 4 \mathrm{~s}$, $£ 215 \mathrm{~s} 6 \mathrm{~d}$, and $£ 32 \mathrm{~s} 6 \mathrm{~d}$ - had been paid to one Grant as the indorsee of this note, except for the first instalment. In Macdonald v Pasley ${ }^{354}$ Macdonald sued Pasley for the full amount while Grant at same time claimed the still unpaid $£ 34 \mathrm{~s}$ as being due to himself.

Macdonald's argument, in short, was that payments to Grant could not discharge Pasley since the note and power of attorney on which they had been made did not comply with the directions of statutes passed to protect sailors and marines "from imposition". ${ }^{355}$ His note was altogether "a less solemn instrument". Pasley simply replied that he was ready to pay into court the $£ 34$ s for the benefit of those to whom it belonged and he requested that all further proceedings on the action should be stayed.

352 See again Anon 1848: 296-297, 319-322.

353 See The Dordrecht (1799) 2 C Rob 55, 165 ER 237 and, generally, Van Niekerk 2005.

354 (1797) 1 Bos \& Pul 161, 126 ER 386 (Ct of CP).

355 Namely, inter alia, that the note had to be revocable, signed and attested before the captain or another naval official, and had to identify the (residence and profession of the) person in whose favour it had been made. 
Eyre CJ dismissed the summary claim on a technicality. The problem here was that Macdonald did not merely claim the $£ 34 \mathrm{~s}$, but the full amount. His contention, it seemed, was that all the money Pasley had paid to Grant had been paid wrongly. It seemed likely that by prescribing the nature of the power of authority under which such payments could be made, the Legislature had intended "that the agent should not be discharged by any thing less than a power of attorney". But here the Court could not interfere and grant the summary claim as Pasley's defence was not appropriate to the claim.

The decision illustrates the unsatisfactory and dilatory way in which prize money was paid. Some sixteen years after the prizes were taken, the final payment of prize shares was still litigated and even then not finalised. ${ }^{356}$

\section{Sutton and Lumley contest a captain's share of the Saldanha Bay prize proceeds}

Although Captain Evelyn Sutton was cleared by his court martial in December $1783,{ }^{357}$ he ultimately failed in his claim to recover damages from his former commander Johnstone when the House of Lords ruled in the latter's favour in May $1787 .{ }^{358}$

However, he had a further ball in his cannon: a claim against his successor on the Isis, Thomas Lumley, for the captain's share of the Saldanha Bay prizes. ${ }^{359}$

It will be remembered that after the battle of Porto Praya, Johnstone had on 21 April 1781 suspended Sutton, had him kept under arrest on the Isis and appointed the Hon Thomas Lumley, commander of the Oporto, in his place as captain until Sutton could be court-martialled. In 1785, Lady Scarborough, the administratrix of the late Captain Lumley, ${ }^{360}$ brought an action for his share of the prize money against the relevant prize agents in the Chancery Court. Matters remained unresolved there, but on the interpleader filed by the prize agents concerned, the Court directed that an action should be brought to determine which of Lumley's representatives or Sutton was in law entitled to the share. ${ }^{361}$

356 See, further, Cooper 1922: 37.

357 See Van Niekerk 2015: par 312.

358 See idem: par 316.

359 There is a reference to this litigation in the Exchequer Chamber's judgment in Sutton v Johnstone (see idem: $\mathrm{n}$ 214). Although Sutton had claimed damages from Johnstone also for having lost his right to a share in the Saldanha Bay prize proceeds, the Court there chose not to give an opinion on whether Sutton had established his loss as the right to the prize money was still in litigation between him and others not party before it.

360 Lumley had died in action in the East Indies in Sep 1782.

361 This is mentioned in Lumley $v$ Sutton at 225-226, 1359, referring to her Ladyship as since deceased. 
A special case was reserved for opinion of the Court of the King's Bench and in Lumley $v$ Sutton $^{362}$ therefore, the issue was whether Lumley or Sutton was entitled to the captain's share of the prize money awarded to the Isis, an amount of $£ 1416$ $13 \mathrm{~s} 4 \mathrm{~d}$.

Further relevant to the issue before the Court was the fact that in terms of the Royal Proclamation of 27 December 1780, all captured and condemned prizes had to be distributed among the captors "for the entire benefit and encouragement of our flag-officers, captains, commanders, and other commissioned officers in our pay; and of the seamen, marines, and soldiers on board our said ships and vessels at the time of the capture". For this purpose, the commanders of ships involved in captures had to transmit to the Commissioners of the Navy a list of the names of all officers, seamen and others who were actually on board at the time of an enemy capture. Captain Lumley had transmitted "a book or prize list" to the Commissioners of the Navy, signed by himself as "acting captain". This list contained the names and quality of all the crew on board the Isis at the time of the Saldanha Bay capture. The list itself did not contain Lumley's name, but that of Sutton was included as "captain". This information was to some extent contradicted by entries in other lists pertaining to the Isis. ${ }^{363}$ Further, Sutton's suspension was with full pay ${ }^{364}$ and neither Lumley nor his representative ever received any additional pay for his services on board the higher-rated Isis, which lasted until he was succeeded, and the suspended Sutton was superseded, by another commander on 2 June 1782. The argument on behalf of Lumley was that Sutton was suspended and not the commanding officer or captain of the Isis, managing her at the time of the capture. His merely being on board at the time was insufficient; one had to actually be acting as captain as well. He was therefore not entitled to a share of the prize money. At the time of the capture Lumley was actually in command and fully responsible and he was the one entitled to the benefits that belonged to that position, even if he had no actual commission then. His position depended on the Proclamation, not on any returns made to the Navy. Further, Lumley could not claim any share of the prize as captain of the Oporto as he was not actually on board her at the time of the capture, and it would be unfair if he were not entitled to share as captain of the Isis for then he would loose out on the prize money altogether. ${ }^{365}$

362 (1799) 8 TR 223, 101 ER 1357 (KB). See, further, Prendergast 1852: 304-305. The Lumley here was the Hon SH Lumley, the Hon Capt Thomas Lumley's administrator de bonis non.

363 In her pay book, signed by the commander who had succeeded Lumley, Sutton's name was included as the captain of the Isis from 28 Aug 1780 until 2 Jun 1782, during which time Lumley's name was in the list of supernumeraries for wages and victuals and after which time, from 2 Jun until 3 Sep 1782, Lumley was entered as captain. Similar entries were made in the muster book of the Isis delivered to Commissioners and also in the purser's muster book.

364 He received his pay as captain of the Isis from the date of his commission until the day of his court-martial acquittal, 11 Dec 1783, and had the usual allowances for servants during that period as captain of the Isis.

365 The point was furthermore made that the principle on which Johnstone $v$ Margetson had been decided (see par 322 above) was also applicable here. 
Sutton, again, contended that he met every description of the person entitled to the prize money. At the time of the capture, he was (still) captain of the Isis and, as confirmed by the returns Lumley had made, the commissioned (his commission was only revoked subsequently) officer in the pay of the naval service. Also, he was on board, even if arrested and suspended. The effect of his suspension, which fell short of his removal, from office, could not deprive him of the advantages belonging to the position as captain, especially given that he was afterwards acquitted by a court martial. As for Lumley, his position was the same as that of a passenger on board and he was merely entitled as such to a smaller share.

On 23 April 1799, the Court of King's Bench determined that the captain of a ship, actually on board at the time of the capture, was entitled to the prize money, even though he was under arrest at the time and even though another officer had been sent to command the ship. The Court accordingly directed that the fund, held by the prize agents, be transferred to Sutton.

At the outset the Court ${ }^{366}$ made it clear that it was not relevant to its decision which of Lumley or Sutton was more worthy to receive the prize money in dispute; they were both officers of great merit and distinction and Sutton had indeed been honourably acquitted by his court martial.

Relevant was the description in the applicable Proclamation of those entitled to claim a share of a prize. And, on the facts, Sutton qualified in every respect with the description of the person entitled to share in the prize money as a captain: he was the captain in naval pay of, and on board, the Isis at the time of the capture.

From the relevant description it appeared that a claim to prize money did not depend on the actual exertions of the captor. It could not be argued that every temporary absence of the captain from the deck - for instance for illness or disability or, as here, arrest - would deprive him of the profits of a captor. Here, at the time of the capture, Sutton had been suspended, but not yet superseded or absolutely dismissed from his ship. All the evidence showed that he was, and had remained, the rated captain of the Isis, and he was actually on board, even if not on deck giving orders, at the relevant time. ${ }^{367} \mathrm{He}$ remained entitled to his pay as captain during his arrest, and he must therefore also have continued to be entitled to all other benefits and emoluments of that rank, even though he may have had no opportunity of exercising his power.

366 Per Lord Kenyon CJ at 228-230, 1360-1361; Grose J at 230, 1361; Lawrence J at 230, 1361.

367 The Court distinguished Wemys $v$ Linzee \& Another (1780) 1 Dougl 324, 99 ER 209. There the captain of marines, who happened to be onboard a warship when she took a prize but did not belong to her compliment, was held entitled to share only as a passenger. Lord Mansfield thought (at 327,211 ) that being "on board" meant belonging to the ship; being accidentally or physically on board was not sufficient. The action there was against Linzee, one of two defendant prize agents, and concerned a prize captured by the warship Surprize under Capt George Linzee, his brother. By some quirk of historical fate, the person Johnstone appointed in the place of Lumley as commander of the Oporto was the very same George Linzee (on occasion also referred to as Lindsay). 
As for Lumley, during the period of Sutton's suspension, he was always identified and considered himself as a mere supernumerary, acting captain, and was as such not entitled to all the advantages to which the actual captain of a ship was entitled. ${ }^{368}$

It appears that the Court's sympathy lay with Sutton. It thought that even though the hardship of the case was not a factor to be considered, nevertheless, having been honourably acquitted by his court martial - and, having been unable to recover damages from Johnstone - it would be "most unjust" to deprive Sutton of his share of the prize money. ${ }^{369}$

\section{Sutton's further and final claim for other shares received by Lumley}

Still Sutton continued his quest for a further share of the Saldanha Bay prize money. This time it was the prize money for the capture of the Held Woltemade and the insurance payout for the two prizes that had been lost en route back to England. The proceeds from this prize and the insurance monies had been paid by the appointed prize agent to Lumley or his legal representative in his capacity as commander of the Isis.

In Sutton v Earl of Scarborough, ${ }^{370}$ then, Sutton claimed the amounts involved, and some others, ${ }^{371}$ from Lumley's personal representative, the Earl of Scarborough. ${ }^{372}$

The latter's plea was based on the Statute of Limitations. If Sutton did have any cause of action, that had accrued more than six years before he had served process.

On 29 July 1803 the Court ${ }^{373}$ overruled Sutton's objections as to its form, and held that the defendant's plea was good.

Thus ended ${ }^{374}$ the litigation concerning the Saldanha Bay prize proceeds, some twenty-two years after the capture of the Dutch prizes there. Appropriately it ended

368 In Waterhouse v King (1802) 2 East 507, 102 ER 463 at 521, 469, Lawrence J distinguished Lumley $v$ Sutton as Lumley was (not commissioned as a second commander but) clearly a supernumerary or occasional officer, neither rated, paid nor returned as captain of the ship nor had any allowance of servants (see also at 522, 469 per Le Blanc J).

369 See also Anon 1848: $328-329$ who has it that Lumley was entitled only to the share of a supernumerary.

370 (1803) 9 Ves Jun 71, 32 ER 528. See also the earlier proceedings in Sutton v Earl of Scarborough (1789) 2 Ves Jun Suppl 145, 34 ER 1031. It must be assumed that the ship called the Helivelmont (!) in the judgment refers to the Held Woltemade.

371 In Feb 1782, the Isis and some other ships captured the French ship Laureston and again the proceeds of this capture were distributed and a considerable sum paid by the prize agent to or on account of Lumley as the captain of the Isis.

372 See at n 360 above for Lady Scarborough's earlier involvement in Lumley's affairs. It appears from the judgment that the decision in Lumley $v$ Sutton, calling money out of the hands of the general prize agents, did not mean that if money was in the hands of Capt Lumley or his agents, that would likewise have been taken from them. Thus, the earlier decision entitling Sutton was effective only as regards money not yet paid over to Lumley but still in the hands of prize agents.

373 Per Eldon LC at 75-76, 529-530.

374 Or maybe not: there is mention in Sutton $v$ Earl of Scarborough of another suit being pending, but I could find no trace of it in the law reports. 
because of the passage of an extended period of time. And one cannot help but feeling some satisfaction on behalf of the late Captain Lumley, who through no fault of his own, would otherwise have lost out quite badly.

\section{Legal consequences at the Cape}

\section{Introduction}

As recounted earlier, ${ }^{375}$ the commanders of the Dutch Indiamen captured by the British in Saldanha Bay - Gerrit Harmeier of the Hoogkarspel, who was also the flag officer of the return fleet, Alex Landt of the Honkoop, Dirk Corneliszoon Plokker of the Paarl, and Hendrik Steedsel of the Dankbaarheid - and of the one that had been destroyed there before she could be captured - Justus van Gennep of the Middelburg - arrived back in Cape Town where they tried to explain to the local authorities what had happened. However, they, like the governor, came in for severe criticism from the Company structures in both Batavia and the Netherlands.

Their conduct was immediately condemned. It was thought that they had been surprised by the enemy through their own neglect ${ }^{376}$ and had failed to obey their orders to destroy their vessels or at least render them unnavigable rather than letting them fall into enemy hands. Clearly they would have to face some disciplinary and possibly criminal sanction. ${ }^{377}$

The Lords Seventeen in Amsterdam, who could not from reports determine in what manner and to what extent the commanders had failed in their duties, ${ }^{378}$ merely expressed the hope that the investigation the Cape authorities had ordered from the fiscal, would be conducted with the necessary rigour, given that in these matters neglect could amount to a criminal offence. ${ }^{379}$

375 Van Niekerk 2015: 420-421.

376 See Jeffreys Kaapse Archiefstukken 1782 Deel 2: 174-175 (Incoming Secret Letters, letter from the Lords Seventeen, dated 2 Nov 1781, received at the Cape 6 May 1782, referring to the fact that "zich door een schandelyk versuijm hebben laten verrasschen").

377 Idem 1783 Deel 1: 354 (Incoming Letters, letter from the Council in Batavia, dated 18 Oct 1782, received at the Cape 23 Feb 1783, referring to possible action concerning "de fataliteit" by the Lords Seventeen "tegens de scheeps overheeden over pligt versuim").

378 Idem 1783 Deel 1: 391-393 (Incoming Letters, letter from the Lords Seventeen, dated 7 Dec 1782, received at the Cape 8 Aug 1783, expressing uncertainty about whether those in charge of the ships had "hun pligt hebben betracht of zij aan uwe order hebben voldaan, off zij in staat zijn geweest, om zich tegens den Vijand te verweeren, en of zoo zij door overmagt tot het verlaaten hunner Scheepen zijn gedwingen, zij geen meerder zorg hadden kunnen draagen, dat de Vijand van die kostbaare Bodems en ladingen geen genot had").

379 Idem 1783 Deel 1: 391-393 (Incoming Letters, letter from the Lords Seventeen, dated 7 Dec 1782, received at the Cape 8 Aug 1783: "zal na alle rigeur zijn gedaan, terwijl in zaaken van dien aart onachtzaamheid zelfs een misdaad is"). 
An idea of the gravity of such offences may be gathered from an instruction, issued during the Fourth Anglo-Dutch War by the Lords Seventeen and sent to the Cape to provide for the reward and encouragement of those engaged in enemy action. ${ }^{380}$ Various rewards were promised ${ }^{381}$ but severe penalties, including death, were also prescribed for those who failed in their duty: "alle trouwloosheeden, lafhartigheeden, of wandevoiren, na vereisch van zaken en goede Krygstugt, zelfs met de dood door hen by vonnis van een Krygsraad zullen worden gestraft."

\section{The criminal investigation at the Cape}

The local government at the Cape had indeed taken immediate steps to have the captains' conduct prior to and during the battle of Saldanha Bay on 21 July 1781 investigated.

On 3 August 1781, the Council of Policy decided to place copies of the commanders' official instructions, correspondence between them and the authorities, and their reports in the hands of the independent fiscal, Willem Cornelis Boers. He was instructed to determine precisely whether and to what extent they had performed their duties properly and had complied with their orders when they abandoned their ships. ${ }^{382}$ If he were to find that they had not, the fiscal was further instructed to take action against them in the Court of Justice. ${ }^{383}$

The highest local court at the Cape, ${ }^{384}$ the Council of Justice ("Raad van Justitie"), had inherent civil and criminal jurisdiction. It served as the appeal court for lower courts which had jurisdiction only in civil matters, and it was therefore the only criminal court in the settlement. ${ }^{385}$ After hearing the evidence in a case, the

380 The order was given in Jul 1781, but was apparently received at the Cape only in Dec 1782(!): see idem 1782 Deel 2: 102-103 (appendices to the Council of Policy Resolution, 2 Dec 1782, referring to a printed "Ordre, g'arresteert door de Extraordinaire Vergadering van Seventienen, gehouden binnen 's Gravenhagen, den 12 July 1781, om te reguleeren de belooningen in cas van Actie, zo voor 't Volk in't algemeen als ieder in 't byzonder").

381 Eg, so many months' salary, or Dutch $f \mathrm{x}$, according to the rank of the performer, and according to the type of action performed (the capture of an enemy warship, the recapture of a Company ship, the destruction of an enemy fireship, the taking down of a flag from an enemy warship, the capture of an armed privateer, the stranding or setting alight of (an enemy) warship or privateer, or extraordinary services).

382 See idem 1781: 113 (Council of Policy Resolution, 3 Aug 1781, instructing Boers "exact onderzoek te doen of en in hoe verre de ... Scheeps-Overheeden hunl pligt behoorlijk hebben opgevolgd, en naargekomen zijn").

383 Ibid ("dezelve voor den Raad van Justitie deeses Gouvernements te actioneeren").

384 On the legal structures at the Cape of Good Hope at the end of the eighteenth century, see, eg, Hahlo \& Kahn 1960: 200-203; Visagie 1969: 40-62; and Hahlo \& Kahn 1973: 543, 566-575.

385 It was established in 1656 as a specially composed Council of Policy ("Raad van Politie") in judicial matters. After reorganisation in 1685 , the Court was pronounced formally separate from the Council although gubernatorial approval was retained; from 1734 it operated under the chairmanship of the second-in-command ("secunde") rather than the governor himself; and from 1785 it was enlarged from eleven members and then consisted of thirteen members (the secunde as chairman, six company officials, and six burgher councillors). 
Court deliberated behind closed doors (foribus clausus) and then gave its judgment. Comprised of legally untrained members, and with no proper instructions ever having been compiled for its operation, the Court's decisions and sentences were and remained subject to approval by the governor before any effect was given to them. Only its actual judgments and sentences were recorded, without any reasons.

Although it acted in the name of the States General in the Netherlands, the Court, it should be stressed, was a Company court, its local judicial arm, and not a Dutch court operating abroad. ${ }^{386}$ It was also a military court ${ }^{387}$ and adjudicated and punished not only crimes committed in the settlement, but also misconduct on Company ships. ${ }^{388}$

Appeals from the Cape Court of Justice lay to the Court of Justice in Batavia as a matter of right. An appeal had to be noted within ten days and prosecuted within one year and involved great expense and delay in that security had to be provided and proceedings had to be sent there. The Batavian Court did not have the power to review decisions rendered at the Cape or elsewhere. ${ }^{389}$

Criminal investigation and prosecution at the Cape at this time ${ }^{390}$ were in the hands of the fiscal, a high-ranking local Company official second only to the governor with wide powers that were open to abuse. Appointed by and directly responsible to the directorate of the Dutch East India Company (DEIC) in the Netherlands, rather than to the local governor, the fiscal had no formal instructions that he had to follow apart from the fact that he had to protect the interests of the Company locally by the enforcement of laws before the Court of Justice. ${ }^{391}$

The fiscal acted as criminal investigator. He was obliged to investigate all alleged crimes, to gather evidence and take down sworn depositions from witnesses, and, where justified, he had to lay a complaint before the Court of Justice. The Court

386 See Ward 2009: 256.

387 Idem: 155.

388 Initially, and prior to the Court being established in 1656, the Council, serving as a court, dealt with disputes on board visiting ships: see Hahlo \& Kahn 1973: 568 n 14; Ward 2009: 69, referring to the Court of Justice in Batavia.

389 The Batavian Council of Justice ("Raad van Justitie"), established in 1626, was both the superior local court and an appeal court, the highest in the empire, for local cases and those coming from elsewhere. For criminal cases (otherwise than for Dutch citizens in civil matters), it was the final court and there was no further resort to courts (such as the "Hoge Raad") in the Netherlands. See, further, La Bree 1951: 81 (the Court of Justice in Batavia heard appeals "[t]egen de vonnissen van de Companiesrechters der buitencomptoiren") and 82; Ward 2009: 17, 69, 71.

390 See, further, Botha 1915: 319-327; Botha 1918: 399-406.

391 He had a seat on the Council of Policy, but after 1685 was made independent of the governor and the Council and directly responsible to the Lords Seventeen. Henceforth he was known as the "independent fiscal". However, his wide and arbitrary powers lead to abuses and to his again being placed under control of the governor in 1793. Botha 1918: $400 \mathrm{n} 3$ explains that the fiscal or butcher bird (lanius collaris) was named after the Company fiscal who was feared by the colonists as that bird was feared by smaller birds. 
then determined whether or not to allow a prosecution and to hear the case and, where necessary, to order an arrest. The fiscal then also acted as public prosecutor and until this privilege was abolished in 1793, he received one-third of all fines imposed or property confiscated as a result of his prosecution of crimes - one-third went to the treasury and another third to the informer. The fact that in petty cases he passed sentence and imposed penalties and fines himself, resulted in further abuses.

Apart from his judicial functions, the fiscal also had important duties concerning ships arriving at or departing from the Cape as he had to render accounts of all such ships' cargoes. ${ }^{392}$

Independent fiscal Boers ${ }^{393}$ reported soon after he had been instructed to do so. On 9 October 1781 the Council of Policy considered his petition regarding the possible prosecution of the Saldanha Bay commanders. ${ }^{394}$

It appeared to Boers that some of them had either not fully or not at all observed their written instructions ("dat Sommige van deselve Overheeden, maar gedeeltelijk en anderen in 't geheel niet hebben geobserveerd gehad, dat geen, het welk aan henl: bij dezelve Schrifteijke Instructie is voorgeschreeven geworden"). However,

392 See idem: 402.

393 Willem Cornelis Boers (1744-1803), a doctor of laws from the University of Utrecht, was appointed senior merchant and independent fiscal ("Oppercoopman en Independent Fiscaal") at the Cape in Jul 1773; he arrived in Dec 1774. His appointment may well have been due to family connections. His uncle, Frederik Willem Boers, was advocate general ("Eerste Advocaat") of the DEIC and a director of the Amsterdam Chamber. Pieter Boers, bailiff of Catwijk, may have been family too, for WC sent him the sum of Rds1 200 in 1783 (see Jeffreys Kaapse Archiefstukken 1783 Deel 1: 490). Although a member of the Council of Policy and the Court of Justice, President of the Orphan Chamber, and the right-hand man of Governor Van Plettenberg, it was the uncontrolled judicial and quasi-judicial powers he exercised as fiscal that made Boers the most hated Company official at the Cape, both by other officials and by burghers. In May 1799, the Cape Patriots in their petition to the Lords Seventeen concerning local malpractices, alluded to his corrupt private commercial dealings with foreigners and visiting ships and his ill-treatment of locals. In Jan 1779, eg, he illegally banished a burgher, CH Buytendag, by having him brutally arrested and incarcerated on the Honkoop which was ready to sail for Batavia. He belatedly defended himself against the accusations in Feb 1781, but also requested to be discharged from his office. This was granted subject to security of Rds5 000 being provided in view of the charges against him ("wegens de beschuldigingen, welke tegens hem door de Caabsche Burgers zyn gedaan"). These were subsequently withdrawn. He left the settlement in Apr 1783 and was succeeded as fiscal by Jan Jacob Serrurier, the first locally-born appointee to the office. See Booyens 1968: 86-87; Ward 2009: 296; Jeffreys Kaapse Archiefstukken 1783 Deel 1:116-117 (Council of Policy Resolution, 6 Apr 783); idem 1783 Deel 1: 294 (Dagregister, 9 Apr 1783); idem 1783 Deel 1: 395 (Incoming Letters, letter from the Lords Seventeen, dated 7 Dec 1782, received at the Cape 8 Aug 1783).

394 See idem 1781: 141-143 (Council of Policy Resolution, 9 Oct 1781). Some of his interrogations are contained in the Cape Archives, CJ 416 (Criminele Proces Stukken: Ondervraging van G Harmeijer, 6 Dec 1781, 635-636); CJ 416 (Criminele Proces Stukken: Ondervraging van A van Ebelshout 12 Dec 1781, 653, 665, 685, 708); CJ 417 (Criminele Proces Stukken, 10 Sep 1781, 191-202); CJ 417 (Criminele Proces Stukken, 15 Sep 1781, 246): see, also, Sleigh 2007: 464 n 417-418 and 465 n 420. 
the commander of the Middelburg not only complied fully ("niet alleen compleetlijk is voldaan geworden") with the strict letter of those instructions, but had even afterwards prevented her capture by setting her alight in such way that she had burnt down completely ("dat het zelve tot aan het Water toe is afgebrand").

As far as the defaulters were concerned, Boers proposed to have them prosecuted as the Council had earlier, on 3 August, instructed him. Given the fact that the captain of the Middelburg had gone beyond any instructions by setting her alight, Boers did not consider himself competent, given the broad scope of his instructions to inquire into all the commanders' conduct generally and without distinction, to make any finding as to his conduct and to excuse him on his own authority of any further investigation ("dezelve eijgener authoriteijt van alle verdere perquisitie bevrijd te laten"). He therefore requested further instructions, specifically whether the Council considered that the officers of the Middelburg had, by setting fire to that ship, complied fully and whether it approved of their conduct, or whether it disapproved, in which case the matter would be left to the Court of Justice. ${ }^{395}$

The Council decided that by setting fire to the hull of the Middelburg, her captain and officers had complied with the spirit and intention of the orders given to the flag officer of the ships in Saldanha Bay, which were all aimed at preventing the ships or their cargoes falling into enemy hands. ${ }^{396}$ Accordingly, the captain and officers of the Middelburg were not to be prosecuted ("niet actionabel zijn") in the present matter. ${ }^{397}$

\section{The criminal prosecution and sentences of the Dutch captains}

In April 1782, Governor Van Plettenberg could report to Amsterdam, and shortly after to Batavia, ${ }^{398}$ that the proceedings the fiscal had brought before the Court of Justice had been completed ("dat de door ged'e Fiscaal ge-entameerde Procedures zeedert bij den Raad van Justitie alhier zijn getermineerd").

395 It seems that according to the fiscal's interpretation of the instructions, they never pertinently ordered or authorised the destruction of the ships themselves. In short, did the order to prevent loss by capture authorise self-destruction to prevent loss by capture?

396 By setting fire to the Middelburg, it was ensured that she would not only not be sailed away by the enemy, but also that they would not be able to take any of her cargo for their own benefit ("is geeffectueerd, dat dien Bodem, niet alleen niet door den Vijand heeft kunnen werden weggevoerd, maar dat denselven zig ook niets van de Lading heeft kunnen ten nutte maken": idem 1781: 141143 (Council of Policy Resolution, 9 Oct 1781).

397 It was not a case that they were prosecuted but found not guilty, as may appear from idem 1782 Deel 1: 164 (Council of Policy Resolution, 7 May 1782, which has it that all the captains were found guilty, except Van Gennep of the Middelburg).

398 See idem 1782 Deel 1: 487 (Outgoing Letters, letter to the Lords Seventeen, dated 28 Apr 1782); idem 1782 Deel 1: 496 (Outgoing Letters, letter to the Council in Batavia, dated 17 May 1782). 
By its sentence of 25 April 1782, the Court suspended captains Harmeier and Landt with the forfeiture of all the salary due to them ("bij Vonisse des Raads van Justitie zijn gesuspendeert in Ampt en Qualiteid met verbeurd verklaaring hunner bij d'E Com'ie te goed hebbende gagie en praemie"), while captains Plokker and Steedsel were sentenced to the forfeiture of their salaries from the date when they had abandoned their ships ("verclaard dezelve zeedert den 21 Jul ... [1781], ... geen gagie bij d'E Comp te hebben gewonnen"). All four were also held to bear the costs of the proceedings against them ("met Condemnatie van alle Vier de gedaagdens in de het Voorm Proces gevallene Costen"). ${ }^{399}$

Amsterdam subsequently requested clarification ${ }^{400}$ on the period of Landt's suspension as no period had been stipulated in the sentence (or at least not mentioned in the earlier correspondence from the Cape). Hoping that it was not the intention of the Court to have it extend beyond Landt's arrival in the Netherlands, the Lords Seventeen declared that his suspension had ceased ("was gecesseerd") but that the remainder of his sentence ("dispositie") was to remain in force as a whole.

And, indeed, the sentences as we have them described, are not clear. ${ }^{401}$ It seems that two of the captains of the captured Indiamen were (at least temporarily) suspended, as opposed to stripped of their rank, and that all forfeited their salaries in a differing extent. ${ }^{402}$

\section{The fate of Captain Pietersz of the Snelheid}

It will be remembered that the hookers with the sails and ropes of the Indiamen on them had been abandoned by their captains and crews in Saldanha Bay, allowing the British to sail their captured prizes home. ${ }^{403}$

Having prosecuted the captains of the captured Indiamen before the Court of Justice, fiscal Boers had no choice but to prosecute the captain of one of the hookers too for what was termed criminal neglect. ${ }^{404}$

The captain of the Snelheid, Roeloff Pietersz, ${ }^{405}$ was likewise found guilty by the Court of Justice for failing to execute his specific orders to burn his vessel. He had had ample opportunity to do so, as she was anchored much further inside the Bay.

399 Idem 1782 Deel 1: 164-165 (Council of Policy Resolution, 7 May 1792).

400 Idem 1783 Deel 1: 394 (Incoming Letters, letter from the Lords Seventeen, dated 7 Dec 1782, received at the Cape 8 Aug 1783).

401 Unfortunately the Court's sentence of 25 April 1782 could not be traced in the Cape Archives.

402 Leibbrandt Precis: 565 (Memorial 51 of 1782) has it that Harmeier and Landt were suspended from their office and rank, with the forfeiture of all the pay and premiums still to their credit, while Steedsel was declared as having earned no pay since 21 Jul 1781; but see, eg, Jeffreys Kaapse Argiefstukken 1782 Deel 1: 164, which has it that all four were stripped of their rank.

403 See, again, Van Niekerk 2015: n 87.

404 See Leibbrandt Precis: $793-794$ (Council letter, dated 14 Jun 1786, 675-676).

405 From Amsterdam, Pieterszoon (also Pieterse, Pietersen) married Rachel Susanna Geere in Dec 1772; the couple had a daughter (b 1774) and a son (b 1778): see De Villiers \& Pama 1966: 697. 
And had he done so, the British would have been unable to sail their unrigged prizes away and may have abandoned them.

Pietersz was stripped of his rank, made to forfeit the pay still due to him, condemned to bear the costs of his prosecution, and declared unfit to be employed by the Company again..$^{406}$

However, he was not satisfied and lodged an appeal to the Court of Justice in Batavia. He applied for and received permission from the Cape authorities to depart with a ship in the roadstead for Batavia with his wife and two children ("zijne huijsvrouw en twee kinderen"). ${ }^{407}$ The Cape authorities informed Batavia, as it was apparently obliged to do, of Pietersz's departure. ${ }^{408}$

The Court of Justice in Batavia allowed the appeal and Pieterzs was restored to his rank and received his pay. ${ }^{409}$ Sadly, it appears, Pietersz died shortly after this success and before he could return to the Cape. ${ }^{410}$

\section{The fate of the captains}

What, then, became of the captains of the six Indiamen captured or destroyed at the Cape in $1781 ?^{411}$

The four who were later, in April 1782, found guilty and forfeiting their salaries - Harmeier of the Hoogkarspel, Landt of the Honkoop, Plokker of the Paarl, and Steedsel of the Dankbaarheid - soon complained that after the unexpected loss of their vessels and their difficult return to the Cape, they were unable to support themselves. Pointing to their many years' of faithful service, they therefore requested to receive the monthly subsistence ("kostgelden en andere Emolumenten") usually granted to Company servants of their rank who had to stay over at the Cape. However, the

406 See Leibbrandt Precis: $793-794$ (Council letter, dated 14 Jun 1786, 676).

407 See Jeffreys Kaapse Archiefstukken 1782 Deel 1: 294 (Council of Policy Resolution, 10 Dec 1782, referring to his request to depart "tot voortsetting van het Appel door hem geinterjecteerd, op ende jeegens Seeker vonnis, bij den raad van Justitie deeses Gouvernements, ten laste van hem supp'lt geveld"). He subsequently received more specific permission to depart for Batavia on the Prussian ship Berlin: see idem 1783 Deel 1: 18 (Council of Policy Resolution, 28 Jan 1783).

408 See idem 1783 Deel 1: 455 (Outgoing Letters, letter to the Council at Batavia, dated 13 Feb 1783, referring to its obligatory notice ("Pligtschuldige kennisse") of his appeal to the "Raad van Justitie des Casteels Batavia" and his departure "ten einde het zelve in Persoon te prosequeeren").

409 See Leibbrandt Precis: 793-794 (Council letter, dated 14 Jun 1786, 676). The Batavian authorities notified the Cape on $24 \mathrm{Feb} 1784$ that in consequence of a written request from the Court of Justice there, based on its verdict of 10 Dec 1783, they had determined to let Pietersz's pay continue from the day on which it had been withheld. He had also been restored to his former rank. As regards the costs he had paid and for the recovery of which the necessary orders had been issued, Pietersz was referred to (the since repatriated) fiscal Boers, or to his agents at the Cape.

$410 \mathrm{Ibid}$, where it is observed that the Cape had not yet received a copy of the Batavian Court's sentence, nor had Pietersz made an appearance here since; private information received stated that he had died in Batavia.

411 Unfortunately I could not obtain a copy of Jaap R Bruijn Commanders of Dutch East India Ships in the Eighteenth Century (2011). No doubt it would have provided much additional information. 
Council of Policy pointed out, criminal proceedings had already commenced against them and that it could not concede to their request. ${ }^{412}$

In another request, some time later, the former commanders pointed out that they had been stranded at the Cape for nine months, had spent the little money they had had, and that they had nothing left with which to maintain themselves or their families and had now also forfeited the salaries due to them. They therefore asked permission to return home in a foreign ship as there was no immediate opportunity to do so in a Company vessel. This request the Council granted. ${ }^{413}$

Later Harmeier, Steedsel and Plokker asked to return home in a specific ship the "keijserlijk particulier Schip Les Etats de Flandres" - on which they had found a passage and to take with them their chests of cargo - "de gepermitteerde kisten van alle Opper en deks Officieren" - that had been landed from their vessels before they were sent to Saldanha Bay, as well as their offloaded personal belongings ("hier meede ontscheepte voetsCasjes").

Harmeijer also requested to be allowed to take his young son, Coenraad, who had been a trainee sailor on his ship, with him, while Plokker sought permission to be accompanied by his brother Simon, who was the third officer on the Honkoop, as well as the young sailor Huyg Jacobsz, of the Paarl. Also, as he had a power of attorney from the carpenter on his ship, Ulve Hendricksz, he requested to take the latter's chest with him to Europe.

The Council gave its permission to these requests, subject to several conditions. For instance, Coenraad Harmeier's salary was terminated ("wiens gagie als jongmattroos à $f 7:-$ p'r maand, over sulx van dato deeses zal moeten Cesseeren"); the chests had to be sealed with the Company's seal, and had to be delivered "op het Oost-Indische Huijs der Camers" to which the returning ships belonged so that their contents could be checked against the invoices issued on their shipment and the relevant duties could be levied. To ensure compliance with these conditions, the captains had to provide security in varying amounts, that would be forfeited should they "in gebreekn mogten blyven" to comply promptly and precisely with their obligations. ${ }^{414}$

412 See Jeffreys Kaapse Archiefstukken 1782 Deel 1: 57-58 (Council of Policy Resolution, 12 Feb 1782, referring to Boers's declaration "dat de aan zyn E geinjungeerde procedures teegens de Suppl'ten reeds voor den Raad van Justitie alhier waren Litispendeerende, en hy Heer Fiscaal eerstdaags van Eysch en Conclusie teegens dezelve stond te dienen"); Leibbrandt Precis: 564 (Memorial 12 of 1782).

413 See Jeffreys Kaapse Archiefstukken 1782 Deel 1: 164-165 (Council of Policy Resolution, 7 May 1792); Leibbrandt Precis: 565 (Memorial 51 of 1782).

414 See Jeffreys Kaapse Archiefstukken 1782 Deel 1: 296-298 (Council of Policy Resolution, 17 Dec 1782); idem 1782 Deel 1: 304-305 (Council of Policy Resolution, 27 Dec 1782); idem 1782 Deel 1: 535-536 (Outgoing Letters, register of letters, where there is a reference to Plokker's request); Leibbrandt Precis: 566 (Memorial 111 of 1782); idem: 922 (Memorial 111 of 1782). It is possible that Simon Plokker left with his brother and later returned, or never left the Cape, for there is a record of a testament of one Simon Plokker, a seaman, in Mar 1785: see Cape Archives, CJ 2639/01/34, 159-162 and CJ 463 ref 35, 163-164. 
Landt requested and received permission ${ }^{415}$ to return to Europe with his son Christiaan, a young sailor on his ship, on board the Portuguese ship Senhor de Bonfim e Sancta Maria that had been chartered by the Cape authorities to convey some of the cargo stranded here back to the Netherlands. ${ }^{416}$ Captain Vrolijk of the Held Woltemade, who was taken prisoner of war by the British when his ship was taken capture, was placed out of Company service as from that date. He was eventually repatriated to the Netherlands. ${ }^{417}$

Lastly, there was Captain Van Gennep of the Middelburg, the only of the commanders to emerge from the events at Saldanha Bay with his reputation intact. Aged thirty-six, he stayed on at the Cape and within a few months, in September 1781, he married a local woman, Elizabeth Johanna van Schoor. Two sons were born from the union. ${ }^{418}$ Like the others, he obtained permission to receive his private-trade goods and to sell it locally at auction, against an undertaking to pay the relevant duties into the local fiscus. ${ }^{419}$

Van Gennep's expertise was soon called upon. He was provisionally put in command of a Danish ship whose captain had been placed under arrest when he ignored an order prohibiting her from departing from the Cape. ${ }^{420}$ Shortly after, in February 1782, he was appointed, as quartermaster ("equipagiemeester") and harbourmaster, in charge of the naval establishment, after the incumbent Damiën Hugo Staring had returned to the Netherlands. ${ }^{421}$ The Lords Seventeen in Amsterdam later approved this appointment, allowing him to retain the rank of captain. ${ }^{422}$ In that capacity he was involved with the survey of Company and other passing ships and reporting on their condition to the governor. ${ }^{423}$ Ironically, in November 1783, when

415 See Jeffreys Kaapse Archiefstukken 1782 Deel 1: 164-165 (Council of Policy Resolution, 7 May 1792); idem 1782 Deel 1: 502 (Outgoing Letters, letter to the Lords Seventeen, dated 28 May 1782); Moree, Perry: 48.

416 See again Van Niekerk 2015: at n 137.

417 See "De brief uit Surhuizum die nooit aankwam (1779), Deel 2" (Apr 2014), available on the website Stamboompagina Sake Wagenaar at http://www.sakewagenaar.nl (accessed 8 Jan 2015).

418 Van Gennep was born 28 Nov 1744 in Gorinchem: see De Villiers \& Pama 1966: 240; http:// www.geni.com and http://geneagraphic.com (both accessed 1 Apr 2015). His and his wife's joint testament, drawn up in Jan 1782, is in the Cape Archives, CJ 2636/01/3; see also CJ 2640/01/17, 77-85 for a testament dated 1786 .

419 Jeffreys Kaapse Archiefstukken 1782 Deel 1: $97-98$ (Council of Policy Resolution, 5 Mar 1782); Leibbrandt Precis: 483 (Memorial 23 of 1782).

420 Jeffreys Kaapse Archiefstukken 1782 Deel 1: 28 (Council of Policy Resolution, 13 Jan 1782).

421 Idem 1782 Deel 1: 56 (Council of Policy Resolution, 12 Feb 1782); Theal 1888: 239, 257.

422 Jeffreys Kaapse Archiefstukken 1783 Deel 1: 395 (Incoming Letters, letter from the Lords Seventeen, dated 7 Dec 1782, received at the Cape 8 Aug 1783, stating "hebbende wij aan denzelven de qualiteijt van captain toegevoegd, doch sonder vermeerdering van gagie").

423 Idem 1782 Deel 1: 182-183 (Council of Policy Resolution, 28 May 1782); idem 1782 Deel 1: 306307 (Council of Policy Resolution, 31 Dec 1782); idem 1782 Deel 2: 149-150 (Memorials and Reports to the Council, Nov 1782); idem 1783 Deel 1: 178-180 (Council of Policy Resolution, 12 Aug 1783). 
the Fourth Anglo-Dutch War was already over, he recommended that the English ship the Content, in such a bad state of repairs that she was in danger of sinking in the roadstead, should be permitted to proceed for repairs to Saldanha Bay, which he suggested was the most fit and proper place for that purpose. ${ }^{424}$ $1801 .^{425}$

Van Gennep returned to the Netherlands in 1786 and died in Rotterdam in

\section{Epilogue}

Thus ended the affair at Saldanha Bay in July 1781. For most of the participants, whether victors or vanquished, there was little immediate or even ultimate gratification. Dilatory legal processes postponed such personal satisfaction or such financial advantage as could be attained for so long as to render them empty.

Nevertheless, even if the judicial proceedings that resulted did not immediately or even ultimately alter the applicable law in any significant and lasting manner, they do enable us, more than 230 years later, to add some new perspectives to the bare bones of an already fascinating episode in the history of the Cape of Good Hope.

\section{Abstract}

Commodore Johnstone's secret mission to the Cape of Good Hope in 1781 had a surprisingly large number of legal consequences, not only in England but also at the Cape. In the main they concerned two matters, namely naval law, more specifically intra-naval immunity, and prize law, more specifically, the question of joint captures. These matters are considered in two parts, of which the first appeared in (2015) 21(2) Fundamina 392-456.

\section{Bibliography}

Anon (1848) "On prize and booty of war" LR \& Quarterly J of British \& Foreign Jurisprudence 8: $282-330$

Botha, C Graham (1915) "Criminal procedure at the Cape during the 17th and 18th centuries" SALJ 32: 319-327

Botha, C Graham (1918) “The public prosecutor of the Cape colony up to 1828" SALJ 35: 399406.

Browne, Arthur (1840) A Compendious View of the Civil Law and of the Law of Admiralty .... vol 2 (1st American ed from 2nd London ed (New York))

424 Idem 1783 Deel 1: 230-231 (Council of Policy Resolution, 18 Nov 1783).

425 See Schutte 1982: 188 n 25; Schutte 2003: 179n; Theal 1888: 257-258. For the liquidation and distribution account drawn up after his death, see Cape Archives, MOOC 13/1/31/01/2, MOOC 13/1/01/16 (Justinus van Gennep: Liquidation and distribution account (1802), (1803)). 
Booyens, B (1968) "Boers, Willem Cornelis" in Dictionary of South African Biography vol 1 (Cape Town)

Cooper, GE (1922) “A day in Westminster Hall, 1797” Mariner's Mirror 8: 35-38

De Villiers, CG revised and rewritten by Pama, C (1966) Genealogies of Old South African Families vol 2 (Cape Town \& Amsterdam)

Hahlo, HR \& Kahn, Ellison (1960) The Union of South Africa. The Development of Its Laws and Constitution [vol 5 The British Commonwealth. The Development of Its Laws and Constitution] (London \& Cape Town)

Hahlo, HR \& Kahn, Ellison (1973) The South African Legal System and Its Background (Cape Town)

Harlow, Vincent (1952) The Founding of the Second British Empire, 1763-1793. Vol 1: Discovery and Revolution (London)

Holland, Thomas Erskine (1888) A Manual of Naval Prize Law, Founded upon the Manual Prepared in 1866 by Godfrey Lushington (London)

Jeffreys, Kathleen M (ed) Kaapse Archiefstukken ... 1781, 1782 Deel 1 en 1782 Deel 2, 1783 Deel 1... (Cape Town, 1930, 1931, 1935, 1938)

La Bree, J (1951) De rechterlijke organisatie en rechtsbedeling te Batavia in de XVIIe eeuw (Rotterdam)

Leibbrandt, HCV Precis of the Archives of the Cape of Good Hope. Requesten (Memorials) 17151806, vol 1: A-E and vol 2: F-O (Cape Town, 1905), vol 3: P-S (Cape Town, 1988), vol 4: T-Z and vol 5: Index (Cape Town, 1989), the volumes with continuous pagination

Marsden, RG (1915) Documents Relating to Law and Custom of the Sea Vol 1: AD 1205-1648 (London)

Moree, Perry "Het superbe legaat van Tante Pieper en andere mysteries: Een inventaris van twaalf bundels Sailing Letters uit de Vierde Engelse Oorlog" available at http:// prizepapersconsortium.huygens.knaw.nl/ (accessed 21 Jan 2015): 47-65

Pasley, Rodney MS (ed) (1931) Private Sea Journals: 1778-1782: Kept by Admiral Sir Thomas Pasley .... (London)

Prendergast, Harris (1852) The Law Relating to Officers of the Navy Part 1 (London)

Phillimore, Robert (1857) Commentaries upon International Law vol 3 (Philadelphia, Pa)

Rutherford, G (1942) "Sidelights on Commodore Johnstone's expedition to the Cape. Part 2" Mariner's Mirror 28: 290-308

Schutte, GJ (ed) (1982) Briefwisseling van Hendrik Swallengrebel Jr oor Kaapse Sake 1778-1792 [Van Riebeeck Society, Second Series no 13] (Cape Town)

Schutte, GJ (ed) (2003) Hendrik Cloete, Groot Constantia and the VOC 1778-1799. Documents from the Swellengrebel Archive [Van Riebeeck Society, Second Series no 34] (Cape Town)

Sleigh, D (2007) Die Buiteposte. VOC-buiteposte onder Kaapse Bestuur 1652-1795 (Pretoria)

Starkey, David J (1990) British Privateering Enterprise in the Eighteenth Century [Exeter Maritime Studies] (Exeter)

Theal, George McCall (1888) History of South Africa [1691-1795] (London)

Van Niekerk, JP (2005) “The First British Occupation of the Cape of Good Hope and two prize cases on joint capture in the High Court of Admiralty" Fundamina. A J of Legal History 11(2): 155-182 


\section{JP VAN NIEKERK}

Van Niekerk, JP (2015) "Of naval court martial and prize claims: Some legal consequences of Commodore Johnstone's secret mission to the Cape of Good Hope and the 'battle' of Saldanha Bay, 1781 (Part 1)" Fundamina. A J of Legal History 21(2): 392-456

Visagie, GG (1969) Regspleging en Reg aan die Kaap van 1652 tot 1806 (Cape Town)

Tiverton, Viscount (1914) The Principles and Practice of Prize Law (London)

Ward, Kerry (2009) Networks of Empire. Forced Migration in the Dutch East India Company [Studies in Comparative World History] (Cambridge)

Wheaton, Henry (1815): A Digest of the Law of Maritime Captures and Prizes (New York, NY)

\section{Cases}

Dordrecht, The (1799) 2 C Rob 55, 165 ER 237

Genoa \& Dependencies, In re Greenwich Hospital Claim (1820) 2 Dods 444, 165 ER 1541

Home v Earl Camden \& Others (1790) 1 H Bl 476, 126 ER 275 (CP)

Home v Earl Camden \& Others (1795) 6 Bro PC 203, 2 ER 1028 (HL); (1795) 2 H Bl 533, 126 ER 687 (HL)

Johnstone v Margetson (1789) $1 \mathrm{H} \mathrm{Bl} 261,126$ ER 153

Lord Camden \& Others v Home (1791) 4 TR 382, 100 ER 1076 (KB)

La Bellone (1818) 2 Dods 343, 165 ER 1508

Lumley v Sutton (1799) 8 TR 223, 101 ER 1357 (KB)

Macdonald v Pasley (1797) 1 Bos \& Pul 161, 126 ER 386 (Ct of CP)

Parker v Toulmin (1786) 1 Cox 264, 29 ER 1159

Sutton v Earl of Scarborough (1803) 9 Ves Jun 71, 32 ER 528

Sutton v Earl of Scarborough (1789) 2 Ves Jun Suppl 145, 34 ER 1031

Waterhouse v King (1802) 2 East 507, 102 ER 463

Wemys $v$ Linzee \& Another (1780) 1 Dougl 324, 99 ER 209

\section{Legislation}

Prize Act, 1778 (18 Geo III c 15)

[French] Prize Act, 1779 (19 Geo III c 5)

[Spanish] Prize Act, 1780 (20 Geo III c 9)

[Dutch] Prize Act, 1781 (21 Geo III c 5)

Navy Act, 1781 (21 Geo III c 15) 